\title{
Oxygen 18/Oxygen 16 and D/H Studies of Plutonic Granitic and Metamorphic Rocks Across the Cordilleran Batholiths of Southern British Columbia
}

\author{
Mordeckai Magaritz ${ }^{1}$ and Hugh P. Taylor, JR.
}

Division of Geological and Planetary Sciences, California Institute of Technology, Pasadena

\begin{abstract}
Hydrogen and oxygen isotope ratios of 500 samples, mainly from granitic plutons, were measured along a 700-km, E-W traverse across the "accreted terranes" of southern British Columbia (latitudes $49^{\circ}-52^{\circ} \mathrm{N}$ ). Despite the geological complexity and range of intrusive ages (Late Triassic to Tertiary) and although there are "steps" in the isotopic values at some geologic boundaries (e.g., across the Strait of Georgia), two clear patterns emerge: (1) The ${ }^{18} \mathrm{O} /{ }^{16} \mathrm{O}$ and $\mathrm{D} / \mathrm{H}$ ratios of the waters involved in hydrothermal interactions with the granitic rocks show a regular eastward trend of depletion in $\mathbf{D}$ and ${ }^{18} \mathbf{O}$. Enormous areas were affected by the hydrothermal processes, but the most intense alteration is localized along major north trending lineaments (e.g., Okanagan Lake). (2) Independent of the hydrothermal effects, the primary $\delta^{18} \mathrm{O}$ values of the granitic rocks also change systematically eastward, from +7.0 to +8.5 in Vancouver Island, reaching a minimum of +5.5 to +7.0 in the western and central Coast Plutonic Complex, then increasing progressively from the eastern Coast Batholith to the Okanagan Batholith, and attaining a maximum of +10.0 to +12.0 in the Nelson Batholith. Two groups of samples are unique in their high $\delta D$ values. The first group is represented by two geographically isolated batholiths (Guichon and Thuya) that were not affected by the Tertiary meteoric-hydrothermal systems and that have therefore preserved their Early Jurassic to Triassic K/Ar ages. The second group is represented by the Jurassic plutons of Vancouver Island; there, the hydrothermal fluids were both D-rich and ${ }^{18} \mathrm{O}$-rich $\left(\delta^{18} \mathrm{O}>0\right)$, as evidenced by the fact that feldspars in the altered granites are enriched in ${ }^{18} \mathrm{O}$ relative to coexisting quartz. Both "anomalies" can be explained if these terranes were located closer to the equator and/or in a maritime environment at the time of intrusive and hydrothermal activity, in agreement with available paleomagnetic data. Excluding these anomalous areas, two distinct ages of meteoric-hydrothermal activity can be identified, Cretaceous in the west and early to mid-Tertiary in the east. The isotopic trends in the rocks are similar to the present-day patterns of meteoric waters in the region, with one primary difference: the paleowaters are enriched in D by about $20 \%$, compatible with a northward translation of these terranes, a climatic change, or both. The similarities of the patterns suggest a topography similar to that of the present day (a mountain chain along the coast) during the early Tertiary. The whole-rock $\delta^{18} \mathrm{O}$ values of the granitic rocks (determined by extrapolation of the trends of $\delta^{18} \mathrm{O}$ quartz versus $\delta^{18} \mathrm{O}$ feldspar, to correct for hydrothermal alteration effects) suggest that the main part of the Coast Plutonic Complex formed from magmas similar to those in oceanic island arcs, derived from basaltic crust or from an upper mantle source. Toward the east, an increasingly larger component of sedimentary rocks must be present in the source regions of the granitic magmas. It may be significant that right at the edge of the North American craton there is a drop in the $\delta^{18} \mathrm{O}$ of the plutons from +11 down to +9.5 , suggesting involvement of old granitic crust instead of sedimentary rocks. These new data from southern British Columbia confirm and amplify previous studies that have documented: (1) the existence of widespread and pervasive hydrothermal effects throughout the North American Cordillera, and (2) regular west-to-east asymmetries in the amounts of different kinds of parent rocks in the source regions from which these Mesozoic and Cenozoic granitic magmas were derived.
\end{abstract}

\section{INTRODUCTION}

In previous hydrogen and oxygen isotope studies [Magaritz and Taylor, 1976a, b], we presented evidence that deep circulation of heated meteoric waters and large-scale interaction of these fluids with granitic plutons accompanied the emplacement of portions of the Coast Plutonic Complex and other intrusive bodies of central British Columbia and southeast Alaska (Figure 1). Similar results were obtained for the Idaho Batholith [Taylor and Magaritz, 1978; Criss and Taylor, 1983]. These investigations also provided information on the origin of the granitic magmas that formed these batholithic complexes.

The purpose of the present study is to extend the above types of studies into southern British Columbia, between the regions described in the above references. This area was selected in order to give us a comprehensive picture of the $\delta \mathrm{D}$ and $\delta^{18} \mathrm{O}$ values of granitic rocks in the northwest Cordillera of

\footnotetext{
${ }^{1}$ Now at Department of Isotope Research, Weizmann Institute of Scrence, Rehovet, Israel.

Copyright 1986 by the American Geophysical Union.

Paper number 5B5445.

0148-0227/86/005B-5445\$05.00
}

North America and because of the availability of a complete section across the Cordilleran batholiths, from southern Vancouver Island eastward to the area where the Nelson Batholith impinges upon the North American craton. This section also cuts across the entire set of "accreted terranes" that have recently been recognized along the western edge of the continent [e.g., Coney et al., 1980; Monger et al., 1982], giving us a chance to look for isotopic variations and possible discontinuities related to the boundaries between different exotic terranes (Figure 1).

The range in age of the granitic intrusions from Late Triassic to mid-Tertiary in the study area is also important with respect to the question of when the effects of surface meteoric waters started to become important in the magmatic history of the region. Another question to be discussed is whether meteoric water is the only type of water involved in the hydrothermal systems; e.g., are sea waters, formation waters, or metamorphic waters also involved? The sources of these different waters can be detected by combining oxygen and hydrogen isotopic measurements of the rocks and hydrous minerals.

Although the different kinds of hydrothermal activity are the main focus of this paper, we also wish to address the problem of the origin of the granitic magmas. Recently, a wealth of new isotopic data have been obtained on other 


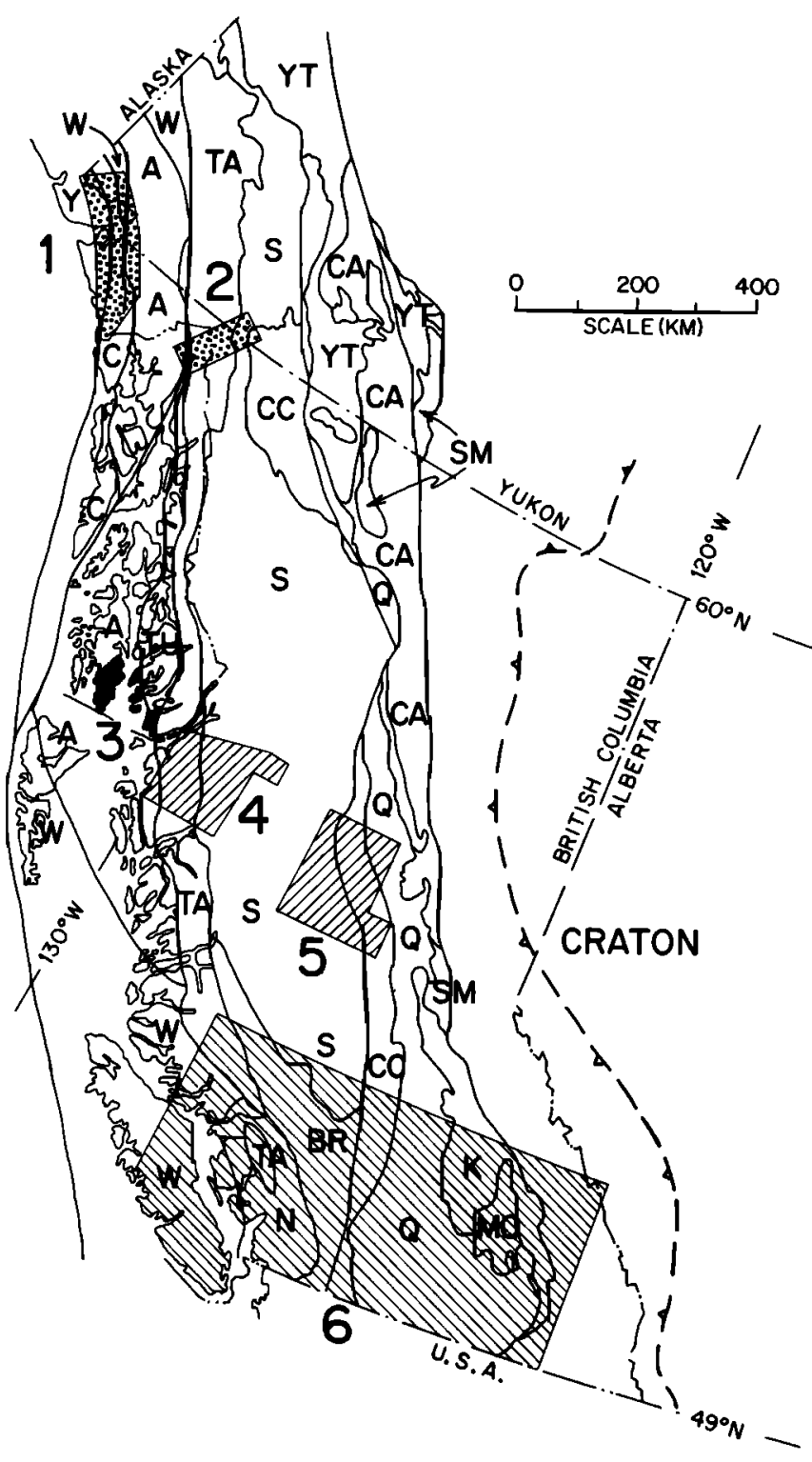

Fig. 1. Index map of British Columbia, showing the positions of the major tectonostratigraphic terranes and the general locations (shaded regions) of the sample traverses for which ${ }^{18} \mathrm{O} /{ }^{16} \mathrm{O}$ and $\mathrm{D} / \mathrm{H}$ analyses were made in this work (position 6), and by Magaritz and Taylor [1976a] (positions 4 and 5), Magaritz and Taylor, [1976b] (positions 1 and 2), and Gehrels and Taylor [1984] (position 3). The positions of the various terranes are based on the compilation by Monger and Berg [1984], generalized by G. Gehrels. W, Wrangellia; N, Nooksack; BR, Bridge River; Q, Quesnel; MO, Monashee; K, Kootenay; CC, Cache Creek, S, Stikine; SM, Slide Mountain; TA, Tracy Arm; A, Alexander; TU, Taku; C, Chugach; Y, Yakutat; YT, Yukon-Tanana; CA, Cassiar.

batholiths along the length of the North American Cordillera [Taylor and Silver, 1978; Silver et al., 1979; Masi et al., 1981; Criss and Taylor, 1983; Solomon and Taylor, 1981], and it is useful to compare these relationships with those in British Columbia, particularly with respect to the effect (if any) that the accreted terranes may have had on the development of the granitic batholiths.

\section{General Geological Relationships}

Although the number of available age determinations in British Columbia is quite large, the reliability of the $\mathrm{K} / \mathrm{Ar}$ ages is questionable when discussing the age of plutonic emplace- ment. This is particularly true in areas where multiple thermal and intrusive events have occurred. For example, in the Coast Plutonic complex, it was noted by Roddick and Hutchison [1974] that K/Ar ages reflect the time of uplift and unroofing of the region, and not the time of emplacement of the plutons. Unfortunately, some of the early Sr isotope data in this area were predicated on the assumption that the ages obtained from the $\mathrm{K} / \mathrm{Ar}$ method reflect the original age of intrusion [Fairbairn et al., 1964].

In some cases, it may be justified to use the $\mathrm{K} / \mathrm{Ar}$ method to give us the age of the youngest intrusive or thermal event and thus date the age of the youngest hydrothermal system in a given area [e.g., Magaritz and Taylor, 1976a; Criss and Taylor, 1983]. In fact, middle to early Tertiary intrusions are widespread in southern British Columbia, Washington, and Idaho. However, during the early Tertiary, wide areas in south central British Columbia were also affected by a thermal event recorded by $\mathrm{K} / \mathrm{Ar}$ resetting in regionally metamorphosed rocks [Mathews, 1981, 1983]. It is very difficult to separate the $\mathrm{K} / \mathrm{Ar}$ effects of intrusive (plus hydrothermal) events versus simple uplift events. In some cases they operate simultaneously [e.g., Criss et al., 1982].

Based on a review of the available literature, Table 1 describes some of the pertinent age relationships for the terranes that we have studied in southern British Columbia.

The section across the Cordilleran batholiths presented in this paper is from a region where the Coast Plutonic Complex reaches its maximum width $(190 \mathrm{~km})$ between latitude $49^{\circ}-$ $52^{\circ} \mathrm{N}$ (Figure 2). This composite batholith is made up almost wholly of plutonic granitic rocks and gneisses, grading eastward into more isolated plutons emplaced into metasedimentary rocks. A summary of the setting and nature of the granitic plutons is given by Gabrielse and Reesor [1974], Roddick and Hutchison [1974], Monger and Price [1979], and Roddick [1983]. Many of the plutons of the Coast Plutonic complex were evidently emplaced at shallow depths in the crust and are classified as mesozonal to epizonal [Gabrielse and Reesor, 1974]. Cenozoic uplift rates are discussed by Parrish [1983].

To the west of the Coast Plutonic Complex, across the 40-km-wide Strait of Georgia, is southern Vancouver Island; this area is composed dominantly of metamorphosed volcanic and volcaniclastic rocks (Wrangellia Terrane) intruded by many small, isolated granitic plutons [Jones et al., 1977; Muller, 1977]. With respect to the abundance of granitic plutons, there is a marked contrast between Vancouver Island and the mainland, even though the coastal area of the mainland is also included in the Wrangellia Terrane (Figure 2). Tertiary intrusions have been locally identified in Vancouver Island (e.g., the Kennedy Lake area), but most of the granitic rocks have well-established Mesozoic ages [Carson, 1973].

In the main part of the Coast Plutonic Complex, plutonism persisted along the same axis for a long period [Peto, 1974], from at least mid-Cretaceous to early Tertiary [Roddick and Hutchison, 1974]; however, earlier magmatic activity is probable. K/Ar determinations indicate that the older (Early Cretaceous) ages are found mainly in the west side of the belt and Tertiary ages are found to the east. $\mathrm{K} / \mathrm{Ar}$ dates range from 140 to $40 \mathrm{Ma}$, typically decreasing eastward [see Parrish, 1983; Figure 2]; the systematics of $\mathrm{K} / \mathrm{Ar}$ ages suggest a sequential uplift and unroofing of the area from west to east [Hutchison, 1982; Roddick and Hutchison, 1974].

East of the Coast Plutonic Complex, the plutons we studied can be divided into three groups: (1) The oldest intrusions recognized in the volcanic rocks of the Intermontane Belt are the Guichon Batholith (198 Ma [Northcote, 1969] and 200 Ma [Chrismas et al., 1968]) and the Thuya Batholith (studied 
TABLE 1. Generalized Age Relationships for the Granitic Batholiths Studied in this Work

\begin{tabular}{|c|c|c|}
\hline Area & $\begin{array}{l}\text { Emplacement Age of } \\
\text { Major Plutonic Episode }\end{array}$ & $\begin{array}{c}\text { Age of Latest } \\
\text { Significant } \\
\text { Intrusive or } \\
\text { Hydrothermal Episode }\end{array}$ \\
\hline Vancouver Island & $180-150 \mathrm{Ma}(\mathrm{K} / \mathrm{Ar})$ & early Tertiary \\
\hline Western Coast Batholith & Late Jurassic-Early Cretaceous & Cretaceous \\
\hline $\begin{array}{l}\text { Central and Eastern Coast } \\
\text { Batholith }\end{array}$ & Cretaceous & $55 \mathrm{Ma}(\mathrm{K} / \mathrm{Ar})$ \\
\hline Guichon Batholith & $190-200 \mathrm{Ma}(\mathrm{K} / \mathrm{Ar})$ & same \\
\hline Thuya Batholith & Late Triassic-Early Jurassic & same \\
\hline Raft Batholith & $140-105 \mathrm{Ma}(\mathrm{K} / \mathrm{Ar})$ & $?$ \\
\hline Okanagan Batholith & $185-150 \mathrm{Ma}(\mathrm{K} / \mathrm{Ar}, \mathrm{Rb} / \mathrm{Sr})$ & $45-50 \mathrm{Ma}(\mathrm{K} / \mathrm{Ar})$ \\
\hline Nelson Batholith & 165-85 $\mathrm{Ma}(\mathrm{K} / \mathrm{Ar}, \mathrm{Rb} / \mathrm{Sr}, \mathrm{U} / \mathrm{Pb})$ & $\sim 50 \mathrm{Ma}(\dot{\mathrm{K}} / \mathrm{Ar})$ \\
\hline
\end{tabular}

Based on references given in the text and by Leech et al. [1963], Lowdon [1961], Medford [1975], Armstrong and Runkle [1979], Wanless et al. [1974, 1979], and Woodsworth et al. [1983].

by Campbell and Tipper [1971]), (2) Middle to Late Jurassic intrusions represent an extensive phase of plutonism in southern British Columbia and include important parts of the Okanagan Batholith [Peto, 1973; Peto and Armstrong, 1976] and the Nelson Batholith [Nguyen et al., 1968; Archibald et al., 1983]. Cretaceous plutons are also probably present but so far have been only poorly delineated by radiometric age dating, (3) scattered early to mid-Tertiary intrusions occur throughout the traverse and are at least partly responsible for widespread resetting of K/Ar ages to values of 40-60 Ma [Godwin, 1975; Medford et al., 1983].

From the published age data in the literature, it seems likely that most of the recorded hydrothermal activity occurred in the Cretaceous to mid-Tertiary time period. We believe that older hydrothermal events also occurred in these areas, but except in certain instances, the evidence is obscure because the rocks have either been eroded away or overprinted by the Tertiary hydrothermal activity. Only in cases where clear differences in the fluid composition exist, as in Vancouver Island, or where older events have been well preserved, as in the 200 Ma Guichon Batholith (or in the Jurassic Topley intrusions farther north; see Magaritz and Taylor [1976a]), are we able to clearly delineate the earlier hydrothermal records.

A recent, widely discussed tectonic model for western North America is the "accreted terrane" concept [e.g., Jones et al., 1977; Saleeby, 1983]. This model is based on sedimentological, paleontological, and paleomagnetic data. The paleomagnetic data suggest that different terranes in British Columbia and Alaska have undergone rotation and translation of the order of 1000 or more kilometers northward relative to the North American craton [Monger and Irving, 1980; Beck et al., 1981; Symons, 1983a, b]. Thus the British Columbia-Alaska region may represent a collage of more than 50 terranes [Coney et al., 1980] that were attached to North America from the Jurassic to the Tertiary (Figure 1). These terranes were grouped into six main units by Monger et al. [1982], two of which are plutonic belts: the Omineca Crystalline Belt and the Coast Plutonic Complex.

The paleomagnetic evidence for northward migration exists not only for sedimentary and volcanic sequences but also for the various batholiths. One of the problems with these models is the fact that the ages of some of the studied plutonic terranes are not well known; thus, in some cases it is not known if the paleomagnetic evidence suggests a fit to the North American plate or not [Monger and Irving, 1980]. For the areas we have examined in the present study, we note the following: (1) The Upper Triassic or Lower Jurassic [North- cote, 1969] Guichon Batholith appears to have been translated northward by $13^{\circ} \pm 6^{\circ}$ of latitude and rotated clockwise $\sim 43^{\circ}$ since emplacement [Symons, 1983]. About $6^{\circ}$ of this translation was apparently earlier than mid-Eocene and $7^{\circ}$ postdates this time [Symons and Litalien, 1984]. (2) The 198 Ma Copper Mountain intrusions indicate a similar $\sim 9^{\circ}$ northward translation and $\sim 39^{\circ}$ clockwise rotation for the Quesnel Terrane farther south [Symons and Litalien, 1984]. From these and other data, Monger and Irving [1980] and Symons and Litalien [1984] suggest about $1400 \mathrm{~km}$ northward motion for the combined Quesnel and Stikine terranes during the Cretaceous and Tertiary. All of these translations and rotations definitely ceased before mid-Miocene time. (3) Paleomagnetic data for the Coast Plutonic Complex imply a similar degree of northward movement $\left(9.5^{\circ}-22.5^{\circ}\right)$ [Beck et al., 1981]. (4) For the Wrangellia Terrane (Vancouver Island), the data suggest migration of more than $3000 \mathrm{~km}$ since the Upper Triassic [Coney et al., 1980; Beck et al., 1981; Panuska and Stone, 1981].

The dates at which these various accretions to the North American plate finally stabilized are not well established. In some cases, the movements may not have terminated until the late Tertiary, although Hillhouse and Gromme [1984], Panuska and Stone [1981], and Stone et al. [1982] conclude that the main period of Wrangellia Terrane drift had pretty well ceased by about $50 \mathrm{Ma}$.

One model suggests that the two belts of crystalline plutonic rocks were emplaced along the suture zones between the main accreted crustal units: Terrane I composed of the Quesnell, Cache Creek, and Stikine terranes and terrane II composed of the Alexander and Wrangellia terranes [Coney et al., 1980; Monger et al., 1982]. The Omineca Belt was emplaced between the North American plate and terrane I, which was accreted during the Late Jurassic, and the Coast Plutonic Belt between terrane I and terrane II, which was accreted during the Cretaceous. Note in this model that the suggested accretion period is the main period of plutonism. However, for these models to be compatible with the paleomagnetic data, then subsequent to accretion, there must have been a major northward translation of these terranes along strike-slip faults parallel to the western edge of the craton. Beck et al. [1981], for example, conclude that the batholiths were formed more than $1000 \mathrm{~km}$ to the south and that they later moved to their present locations along major transform faults. The positions of these terranes at the time of batholith formation obviously have important consequences with respect to magma generation and emplacement, as well as to the climatic environ- 


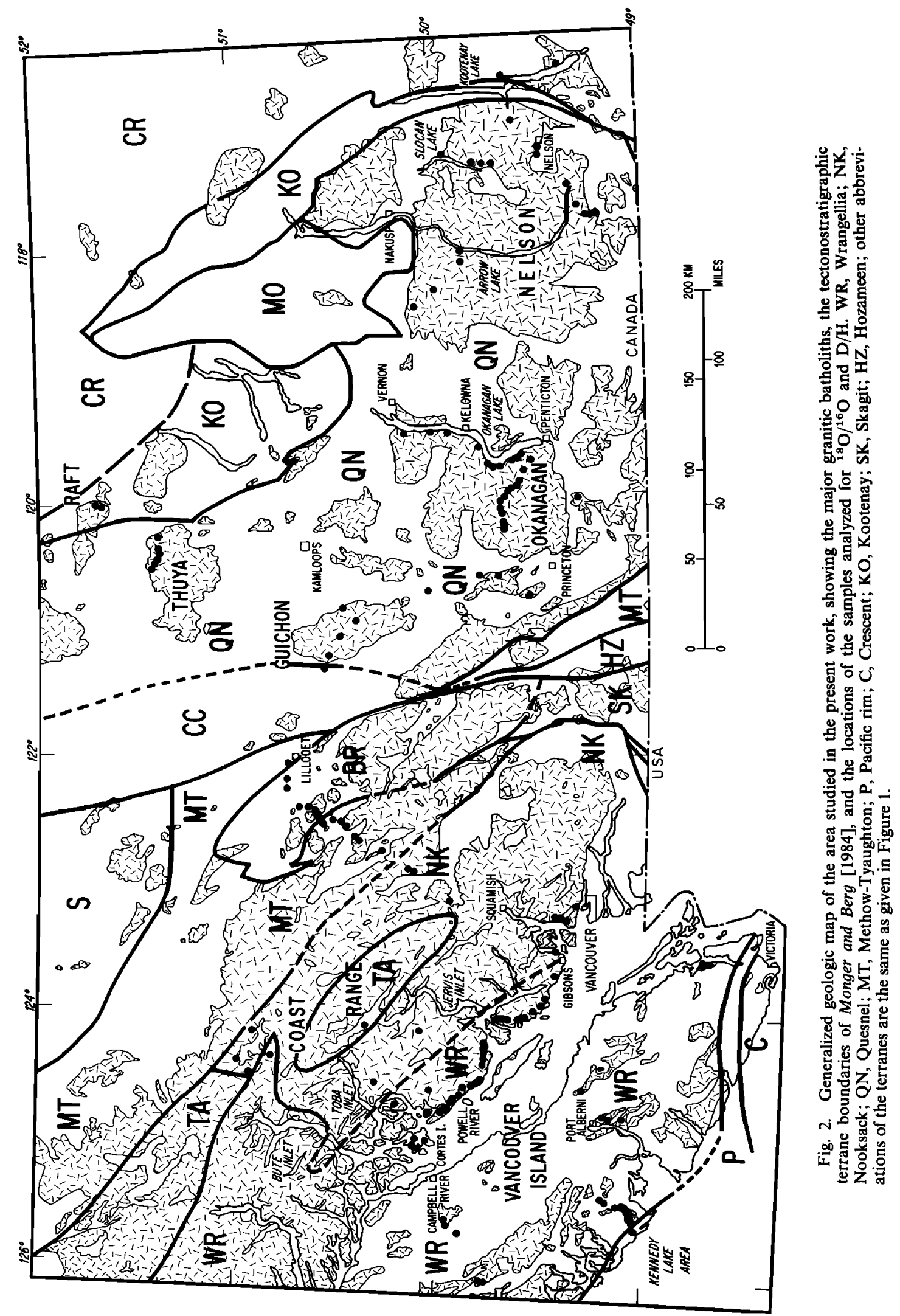


ments where hydrothermal alteration takes place (as this controls the isotopic compositions of surface waters in those areas).

\section{ANalytical Results}

Figures 1 and 2 indicate the locations of the analyzed samples, and the analytical data are presented in Tables $2-7$. Thin sections and $\mathrm{X}$ ray powder diffraction patterns of all the samples were studied to identify the major minerals in each sample and to assure the purity of the mineral separates.

Oxygen for isotopic analyses was liberated from silicate samples by reaction with fluorine gas at $500^{\circ}-560^{\circ} \mathrm{C}$, in the manner described by Taylor and Epstein $[1962 a, b]$. For D/H analysis, hydrogen gas was extracted from the mineral separate [see Magaritz and Taylor, 1976a] in the manner described by Godfrey [1962]. Isotopic data are reported in the familiar $\delta$ notation in per mil relative to SMOW. NBS-28 has a $\delta^{18} \mathrm{O}=+9.60$ on this scale. The analytical errors are $0.1-0.2 \%$ for oxygen and about $1-2 \%$ for hydrogen.

Our ability to decipher the primary $\delta^{18} \mathrm{O}$ values of igneous rocks that have been hydrothermally altered is based on the fact that oxygen exchange between aqueous fluids and the two most common silicate minerals, quartz and feldspar, occurs at different rates [Taylor and Forester, 1971; Magaritz and Taylor, 1976a; Taylor, 1977; Criss and Taylor, 1983]. On a $\delta^{18} \mathrm{O}$-quartz versus $\delta^{18} \mathrm{O}$-feldspar diagram (see Figure 13 below), data points from hydrothermally altered granitic rocks typically form a linear array with a slope much steeper than $45^{\circ}$. We can extrapolate this array back to the appropriate primary magmatic $\delta^{18} \mathrm{O}$ values of the unaltered rocks by observing where the array would intersect the $45^{\circ}$ lines for $\Delta^{18} \mathrm{O}$ quartz-feldspar $(\approx 1.0-1.5$ for alkali feldspar or $1.5-2.0$ for plagioclase). We can also directly determine the $\delta^{18} \mathrm{O}$ of the original quartz in a granitic rock by carrying out partial fluorination experiments on the quartz crystals (see Figure 12 below). This procedure reveals the $\delta^{18} \mathrm{O}$ value of the unaltered cores of the quartz grains [Magaritz and Taylor, 1976a].

For identification of the isotopic composition of the hydrothermal fluid, it is important to study the $\mathrm{D} / \mathrm{H}$ ratios of the hydrous phases in the rock. The hydrogen isotopes are much more sensitive to small degrees of water/rock interaction than are the oxygen isotopes because the hydrogen concentrations in rocks are very small. At a water/rock ratio $\geq 0.1$ (mass units), the $\delta \mathrm{D}$ values of the OH-bearing minerals in the rock are completely controlled by the external fluid (e.g., see Figure 8 of Taylor [1977] or Figure 3 of Taylor and Magaritz [1978]), leading to a characteristic "inverted-L" shaped pattern on a $\delta \mathrm{D}-\delta^{18} \mathrm{O}$ diagram.

\section{Wrangellia Terrane}

\section{Vancouver Island}

Most granitic plutons on Vancouver Island are intruded into the Karmutsen Formation, a eugeosynclinal sequence that is equivalent in age to the Cache Creek, Takla, and Nicola groups of mainland British Columbia. The Karmutsen Formation has a well-established Late Triassic age [Carlisle and Susuki, 1974]. The plutons are mainly granodiorites to quartz diorites, and except for scattered Tertiary intrusions throughout the island [Carson, 1973], they are Middle to Late Jurassic in age (181-150 Ma K/Ar ages [Carson, 1973]). All of the granitic rocks sampled by us come from this age group except for the Kennedy Lake area, which contains several Tertiary intrusions.

The granitic rocks of Vancouver Island typically display moderate alteration, evidenced by clouding of the plagioclase, chloritization, and prehnite lenses. A reasonable estimate of the depth of emplacement of the Jurassic intrusions is between 3 and $6 \mathrm{~km}$ [Carson, 1973]. This is well within the range where large convective hydrothermal circulation systems are commonly developed around granitic plutons [Taylor, 1977].

For purposes of discussion, the analyzed granitic rocks from southern Vancouver Island are subdivided into lour geographic groupings (Table 2, Figure 3): south, two granodiorites from the Cobble Hill-Mill Bay area $30 \mathrm{~km}$ northwest of Victoria; central, three samples from the Port Alberni area; north, four samples from the Gold River-Quinsam Lake area to the west of the town of Campbell River; and Kennedy Lake, several samples near the western coast of Vancouver Island, $50-60 \mathrm{~km}$ west of Port Alberni.

Although the number of samples is small, it is encouraging that the isotopic compositions of each of the four geographic groups separate nicely on Figure 3. The most important separation on Figure 3 is that between the low $\delta \mathrm{D}$ values of Kennedy Lake samples and the much higher $\delta D$ values found on the rest of the island; note that the ${ }^{18} \mathrm{O} /{ }^{16} \mathrm{O}$ data for all the sample groupings are generally similar.

The $\delta^{18} \mathrm{O}$ values of quartz from eight granodiorites and quartz monzonites on Vancouver Island are very uniform at +7.7 to +9.7 , implying that the original, prehydrothermal $\delta^{18} \mathrm{O}$ values of these rocks were about +7.0 to +9.0 , similar to most other granitic rocks throughout the world. However, some of the granitic rocks on Vancouver Island are very unusual in that they have negative $\Delta^{\mathbf{1 8}} \mathrm{O}$ quartz-feldspar (Q-F) values (Table 2, Figure 3). These samples are from the Saanich pluton $\left(\Delta^{18} \mathrm{O}_{\mathrm{Q}-\mathrm{F}}=-1.9\right)$ and from the Kennedy Lake complex $\left(\Delta^{18} \mathrm{O}_{\mathrm{Q}-\mathrm{F}}=-2.0,-0.9\right)$, and in all such samples the mafic minerals are intensely chloritized (Table 2 ). The negative $\Delta^{18} \mathrm{O}$ values indicate pronounced isotopic disequilibrium and imply that the high $\delta^{18} \mathrm{O}$ feldspar values found in these rocks $(+9.6$ to +11.7$)$ are a result of postcrystallization hydrothermal effects at relatively low temperatures $\left(\approx 200^{\circ}-\right.$ $300^{\circ} \mathrm{C}$ ), where quartz is very resistant to isotopic exchange but where feldspar readily undergoes appreciable ${ }^{18} \mathrm{O}$ enrichment in the presence of hydrothermal fluids with $\delta^{18} \mathrm{O} \geq 0$.

In contrast to all the other hydrothermally altered samples farther to the east (see below) and particularly to those just across the Strait of Georgia, there is no evidence anywhere on Vancouver Island for the presence of low- ${ }^{18} \mathrm{O}$ hydrothermal fluids (i.e., $\delta^{\mathbf{1 8}} \mathrm{O}_{\mathrm{H}_{2} \mathrm{O}} \leq 0$ ). None of the feldspars on Vancouver Island appear to have undergone a depletion in ${ }^{18} \mathrm{O}$; even in the lowest- $\delta \mathrm{D}$ samples (the Kennedy Lake area), the feldspars either retained their primary $\delta^{18} \mathrm{O}$ values or they became enriched in ${ }^{18} \mathrm{O}$. This conclusion is supported by other data in Table 2 , such as the $\delta^{18} \mathrm{O}$ values of quartz veins $(+9.6$ to +12.6 ), calcite veins $(+4.7$ to +8.9$)$, and disseminated calcite in a chloritized porphyry $(+10.0)$.

The $\delta \mathrm{D}$ values of the granitic rocks from Vancouver Island vary from -53 to -94 , and in most of the analyzed rocks the water comes from chlorite, which replaced the original hornblende (Table 2, Figure 3). The chlorites from the Kennedy Lake samples, the youngest and westernmost granitic plutons analyzed, all have much lower $\delta \mathrm{D}$ values $(-80$ to -94$)$ than the chlorites from the rest of the granitic rocks $(-53$ to -72$)$. These samples were collected in the vicinity of Tertiary plutons and have apparently interacted with meteoric waters having significantly lower $\delta \mathrm{D}$ values (but similar $\delta^{18} \mathrm{O}$ values) than those that affected other rocks on Vancouver Island. The high $\delta \mathrm{D}$ values from other parts of the island most likely indicate marine pore fluids or formation waters (see below).

Five chloritized xenoliths embedded in various granitic plutons in southern Vancouver Island were analyzed (Table 2). In 
TABLE 2. Oxygen, Hydrogen and Carbon Isotope Analyses of Minerals and Rocks From Vancouver Island

\begin{tabular}{|c|c|c|c|c|c|c|c|}
\hline Sample & $\begin{array}{l}\text { Rock Type and } \\
\text { Mineralogy }\end{array}$ & $\delta D$ & $\begin{array}{c}\delta^{18} \mathrm{O} \\
\text { Whole Rock }\end{array}$ & $\begin{array}{l}\delta^{18} \mathrm{O} \\
\text { Quartz }\end{array}$ & $\begin{array}{c}\delta^{18} \mathrm{O} \\
\text { Feldspar }\end{array}$ & $\begin{array}{c}\delta^{18} \mathrm{O} \\
\text { Mineral }\end{array}$ & $\begin{array}{c}\delta^{13} \mathrm{C} \\
\text { Carbonate }\end{array}$ \\
\hline \multicolumn{8}{|c|}{ Southern Area (Mill Bay) } \\
\hline 135 & GD-f, k, c, q & $-56 c$ & & 9.4 & 11.3 & & \\
\hline 136 & GD-f, k, c, q, h & $-72 c$ & & & 9.6 & & \\
\hline $136 a$ & DI(XEN)-f, h, c & $-59 h+c$ & & & & & \\
\hline \multicolumn{8}{|c|}{ Kennedy Lake Area } \\
\hline 138 & GD-f, k, q, b, c, h & $-89 b+h+c$ & & 9.2 & 7.9 & & \\
\hline 139 & LI-ca, [ca] & & & & & $11.6 \mathrm{ca},[4.7 \mathrm{ca}]$ & $-0.3 \mathrm{ca},[-10.4 \mathrm{ca}]$ \\
\hline 140 & DI-f, q, c & $-87 c$ & 9.3 & & 9.6 & & \\
\hline 141 & $\mathrm{QM}-\mathrm{k}, \mathrm{f}, \mathrm{q}, \mathrm{c}$ & $-94 c$ & & 8.9 & 9.9 & & \\
\hline 143 & $\mathrm{BA}-\mathrm{f}, \mathrm{a},[\mathrm{e}]$ & $-66 \mathrm{a},[-55 \mathrm{e}]$ & & & & & \\
\hline 144 & PO-k, f, q, c, ca & $-88 \mathrm{c}$ & 11.1 & & & $10.0 \mathrm{ca}$ & $-6.4 \mathrm{ca}$ \\
\hline 145 & BA-f, cp, c, h & $-87 c+h$ & 5.6 & & & & \\
\hline 147 & GRN-k, f, q, c & $-88 c$ & & 9.7 & 11.7 & & \\
\hline $147 \mathrm{a}$ & $\mathrm{BA}(\mathrm{XEN})-\mathbf{f}, \mathrm{c}, \mathbf{a}$ & $-68 c+a$ & 10.5 & & & & \\
\hline $147-1$ & $B A-c p, f, a, c$ & $-85 c+a$ & 6.5 & & & & \\
\hline 150 & QD-f, q, c & $-80 c$ & & & 11.3 & & \\
\hline 151 & BA-f, c, $[e, q, c a]$ & $-86 c,[-24 \mathrm{e}]$ & 7.8 & {$[9.6]$} & & {$[8.9 \mathrm{ca}]$} & {$[-2.5 \mathrm{ca}]$} \\
\hline \multicolumn{8}{|c|}{ Central Area (Port Alberni) } \\
\hline 153 & DI-f, h, c & $-63 c+h$ & & & 9.9 & $7.8 \mathrm{~h}$ & \\
\hline 157 & $B A-f, c p, c, a, c a$ & $-57 c+a$ & 10.6 & & & & \\
\hline 159 & GD-f, k, q, h, c & $-82 h(+c)$ & & 9.5 & 8.7 & & \\
\hline 160 & GRN-k, q, f, h & $-67 h$ & & 7.7 & $7.4,8.1 \mathrm{k}$ & & \\
\hline \multicolumn{8}{|c|}{ Northern Area (Gold River-Quinsam Lake) } \\
\hline 165 & GD-f, k, q, c, h & $-60 c+h$ & & 8.8 & 6.0 & & \\
\hline 167 & QM-q, f k, c, h, b & $-59 c+h$ & & 8.2 & 6.6 & & \\
\hline $167 a$ & AND(XEN)-q, $\uparrow, \mathbf{k}, \mathbf{h}, \mathbf{c}$ & $-62 \mathrm{c}$ & 10.3 & & & & \\
\hline 169 & BA-f, cp, c, [q, z] & $-79 c,[-44 z]$ & 7.9 & [12.6] & & & \\
\hline 170 & DI-f, h, c & $-63 h+c$ & & & 6.5 & & \\
\hline 171 & GD-f, q, c, h & $-53 c$ & & & 8.2 & & \\
\hline 171a & PO(XEN)-f, q & & & & 5.4 & & \\
\hline $141 b$ & DI(XEN)-f, c, h & $-46 c+h$ & 7.1 & & & & \\
\hline
\end{tabular}

GD, granodiorite; DI, diorite; LI, limestone; QM, quartz monzonite; BA, basalt; PO, porphyry; GRN, granite; QD, quartz diorite; AND, andesite; XEN, xenolith; A, aplite; D, dike; MIG, migmatite; PEG, pegmatite; SCH, schist; V, vein; GB, gabbro; GN, gneiss. f, plagioclase; $k$, $\mathrm{K}$ feldspar; c, chlorite; q, quartz; h, hornblende; b, biotite; ca, calcite; e, epidote; a, actinolite; cp, clinopyroxene; z, zeolite; ser, sericite; m, muscovite. Brackets indicate that analyzed mineral is from a crosscutting vein.

most cases the $\delta \mathrm{D}$ values of the xenoliths are similar to those of the host rocks, compatible with pervasive subsolidus exchange with hydrothermal fluid. The only exception is a sample from the Kennedy Lake area, where the $\delta \mathrm{D}$ of a basaltic xenolith (147a) is $20 \%$ higher than in the host granite; this xenolith thus appears to have preserved the high- $\delta \mathrm{D}$ value characteristic of the rest of Vancouver Island, even though the host pluton attained the much lower- $\delta \mathrm{D}$ value that seems to be characteristic of the Tertiary hydrothermal event that affected the Kennedy Lake complex.

Basaltic samples (Table 2) of the Karmutsen Formation are typically enriched in ${ }^{18} \mathrm{O}$ (up to $\delta^{18} \mathrm{O}=+10.6$ ) compared to the +5.5 to +6.5 values characteristic of fresh basalts [Taylor, 1968]. Similar $\delta^{18} \mathrm{O}$ values are observed in xenolithic fragments of these volcanic rocks embedded in the granitic plutons (Table 2). The Karmutsen Formation thus appears to have undergone a modest degree of ${ }^{18} \mathrm{O}$ enrichment during prehnite-pumpellyite facies burial metamorphism prior to the intrusion of the plutons [Kuniyoshi and Liou, 1976]. The ${ }^{18} \mathrm{O}$ enrichments and the $\delta \mathrm{D}$ values of chlorites and actinolites in these basalts $(-57$ to -87$)$ are both similar to the values observed in the granitic rocks throughout Vancouver Island. The isotopic effects are also similar to those observed in other low-grade eugeosynclinal terranes, such as the Franciscan Formation of California [Magaritz and Taylor, 1976c]. However, note that the basaltic country rocks in the vicinity of the Kennedy Lake area have relatively low $\delta \mathrm{D}(-85$ to -87$)$ compared to other parts of Vancouver Island ( $\delta \mathrm{D}$ as high as $-57)$.
Except for the Kennedy Lake area (Tertiary plutons), the isotopic data from Vancouver Island suggest that a similar type of water was involved in both the hydrothermal alteration of the Mesozoic granitic rocks and in the albitization and burial metamorphism of the Late Triassic Karmutsen basalts. This water had relatively high $\delta \mathrm{D}$ and $\delta^{18} \mathrm{O}$ values. Several types of water can be suggested as hydrothermal agents, but marine pore fluids would seem to be most appropriate. The fact that some of the feldspars in the granitic rocks have been enriched in ${ }^{18} \mathrm{O}$ by at least $2-3 \%$ after crystallization requires either a high- ${ }^{18} \mathrm{O}$ water (similar to "magmatic water") at almost magmatic temperatures or water with $\delta^{18} \mathrm{O}$ no lower than zero (such as seawater or exchanged seawater) at temperatures lower than $200^{\circ} \mathrm{C}$ (e.g., at $150^{\circ} \mathrm{C}, \Delta^{18} \mathrm{O}$ feldspar- $\mathrm{H}_{2} \mathrm{O}=10.5$ for $\mathrm{An}_{50}$ plagioclase [ $\mathrm{O}^{\prime}$ Neil and Taylor, 1967]). This hydrothermal ${ }^{18} \mathrm{O}$-enrichment event was apparently very widespread and pervasive, as evidenced by sample 139 , a limestone whose $\delta^{18} \mathrm{O}=+11.6$ indicates at least a $15 \%$ lowering from its original marine $\delta^{18} \mathrm{O}$ value.

We conclude that marine pore fluids or formation waters would be adequate to explain most of the isotopic data on Vancouver Island. However, in view of the paleomagnetic evidence, meteoric waters also represent a plausible component of the fluids (i.e., if this terrane was considerably closer to the equator than at present and/or if the area was an island with a subtropical maritime climate). Geological and geophysical evidence in fact strongly suggest that Vancouver Island (Wrangellia) was not part of North America at the time these plutons were emplaced [Berry et al., 1971; Coney et al., 1980], 


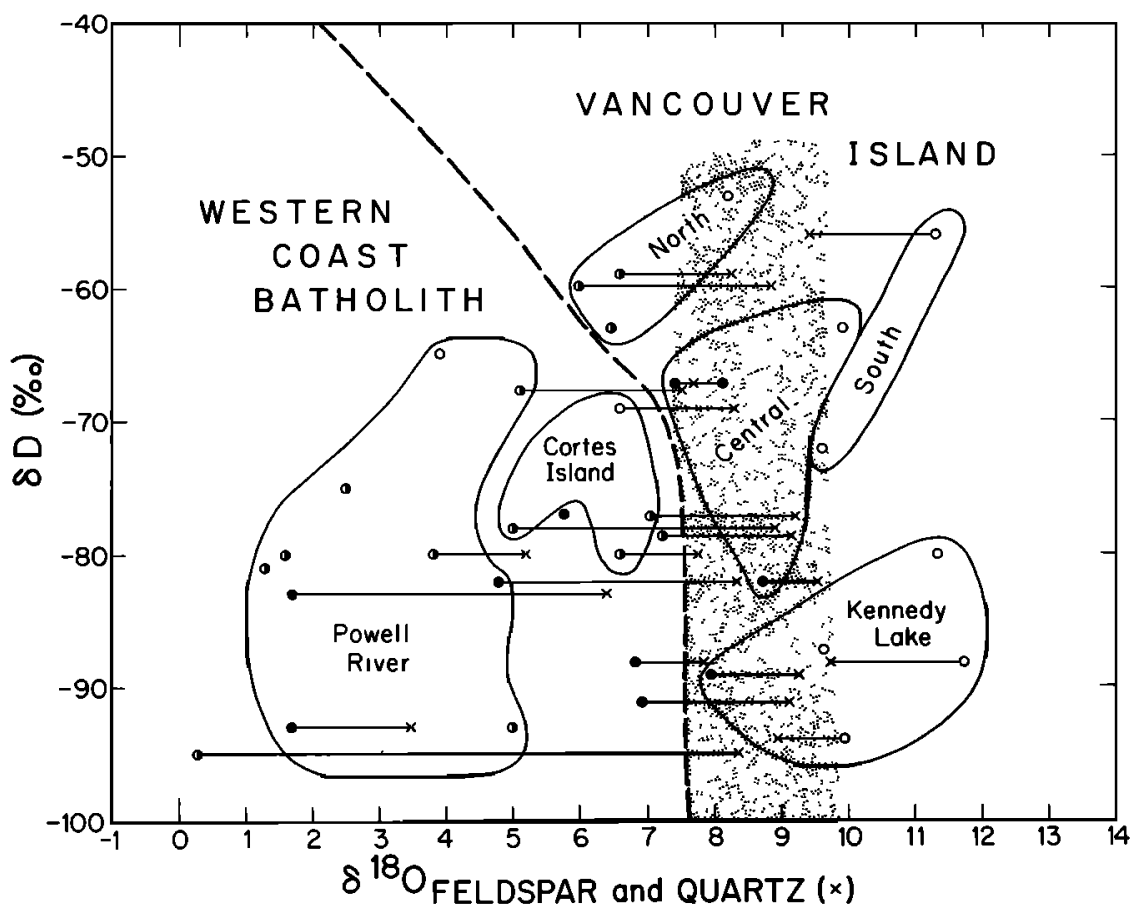

Fig. 3. Plot of $\delta \mathrm{D}$ versus $\delta^{18} \mathrm{O}$ feldspar and quartz for samples of granitic rocks from the Wrangellia Terrane studied in the present work. The range of feldspar $\delta^{18} \mathrm{O}$ values in various geographic regions is indicated by the envelopes around the data points. The stippled zone encompasses most of the $\delta^{18} \mathrm{O}$ quartz values from this large region (see text). Solid dots indicate relatively pure biotite and/or hornblende; half-solid dots indicate moderate to strong chloritization of mafic minerals; and open dots indicate completely chloritized samples. Horizontal tie lines connect coexisting quartz and feldspar from the same sample.

and paleomagnetic results indicate a possible magnetic latitude of $18^{\circ} \mathrm{S}$ for the Late Triassic rocks of the Island [Yole and Irving, 1980].

\section{Western Coast Plutonic Complex}

Like Vancouver Island, the country rocks of the western part of the Coast Plutonic Complex are included in the Wrangellia Terrane by most workers [e.g., Monger and Berg, 1984]. However, as shown in Figure 3, some major oxygen isotopic differences are observed between the granitic rocks on Vancouver Island and those on the mainland $40-60 \mathrm{~km}$ to the east across the Strait of Georgia. Isotopic differences even show up across the much narrower channel between north central Vancouver Island and Cortes Island at the north end of Strait of Georgia (Figure 2). The Cortes Island granitic rocks are thus isotopically as well as geographically intermediate between those of Vancouver Island and those from the nearby Powell River traverse on the mainland (Figure 3).

The sampled area along the western edge of the Coast Plutonic complex (Figure 2) is somewhat arbitrarily divided into three zones for purposes of discussion: (1) Cortes Island, (2) Powell River area, and (3) other samples, most of which are located southeast of the Powell River traverse along the Coast Highway (Route 101) between Earl's Cove and Gibsons Landing but which also include three samples from the interior, $10-25 \mathrm{~km}$ inland from the coast $(10039,10230$, and 30436$)$.

The $\delta \mathrm{D}$ values of granitic rocks from the Western Coast Batholith vary from -65 to -95 , excluding one highly chloritized sample with $\delta D=-109$ (Table 3). Except for this anomalous sample, the $\delta \mathrm{D}$ values vary in a systematic fashion with respect to the mineralogy of the $\mathrm{OH}$-bearing phases; the most heavily chloritized samples have the highest $\delta \mathrm{D}(-65$ to -69 ), and the least chloritized samples with fresh biotite and hornblende tend to have the lowest $\delta \mathrm{D}(-77$ to -93$)$. Al- though the $\delta \mathrm{D}$ results in Figure 3 could simply represent various degrees of physical mixing between hydrothermal chlorite and primary magmatic hornblende and biotite, we should note that at moderate temperature $\left(300^{\circ}-500^{\circ} \mathrm{C}\right)$ during equilibrium $\mathrm{D} / \mathrm{H}$ exchange with a hydrothermal fluid, chlorite will in fact concentrate deuterium relative to biotite and hornblende. Thus the observed effects can also be explained by pervasive exchange with a single hydrothermal fluid having $\delta \mathrm{D}=-40$ to -60 [Suzuoki and Epstein, 1976].

This hydrothermal fluid must have had a very low $\delta^{18} \mathrm{O}$ value, locally as low as -5 or even lower, and must have exchanged with these rocks in vast quantities, because (1) most of the rocks in this area, particularly those from the Powell River traverse, are strongly depleted in ${ }^{18} \mathrm{O}$, with $\delta^{18} \mathrm{O}$ feldspar values commonly as low as +1 to +2 , and (2) the $\Delta^{18} \mathrm{O}$ quartz-feldspar values are very large, indicating that locally the $\delta^{18} \mathrm{O}$ of the feldspar has been "pulled down" as much as $7 \%$ more than has the $\delta^{18} \mathrm{O}$ of coexisting quartz in the same rock. This discovery that there has been pervasive hydrothermal alteration of this entire terrane was a big surprise to us because we earlier had found no such evidence in the equivalent position in the batholith farther north in the Prince Rupert area [Magaritz and Taylor, 1976a]. The only physical evidence of such alteration in the present study area is the presence of very large numbers of veins and fractures, which are locally filled with abundant epidote. Also, there is occasionally a development of reddish feldspars, which elsewhere has been shown to go hand in hand with low-temperature hydrothermal ${ }^{18} \mathrm{O}$ exchange [Wenner and Taylor, 1976; Taylor, 1974a].

To investigate the hydrothermal alteration event(s) in more detail, several samples of feldspar were analyzed directly adjacent to prominent epidote-bearing veins for direct comparison with feldspar from the nearby bulk rock (Table 3). In situ- 
TABLE 3. Oxygen and Hydrogen Isotope Analyses of Minerals and Rocks From the Powell RiverCortes Island-Gibsons Landing Areas in the Western Part of the Coast Range Batholith

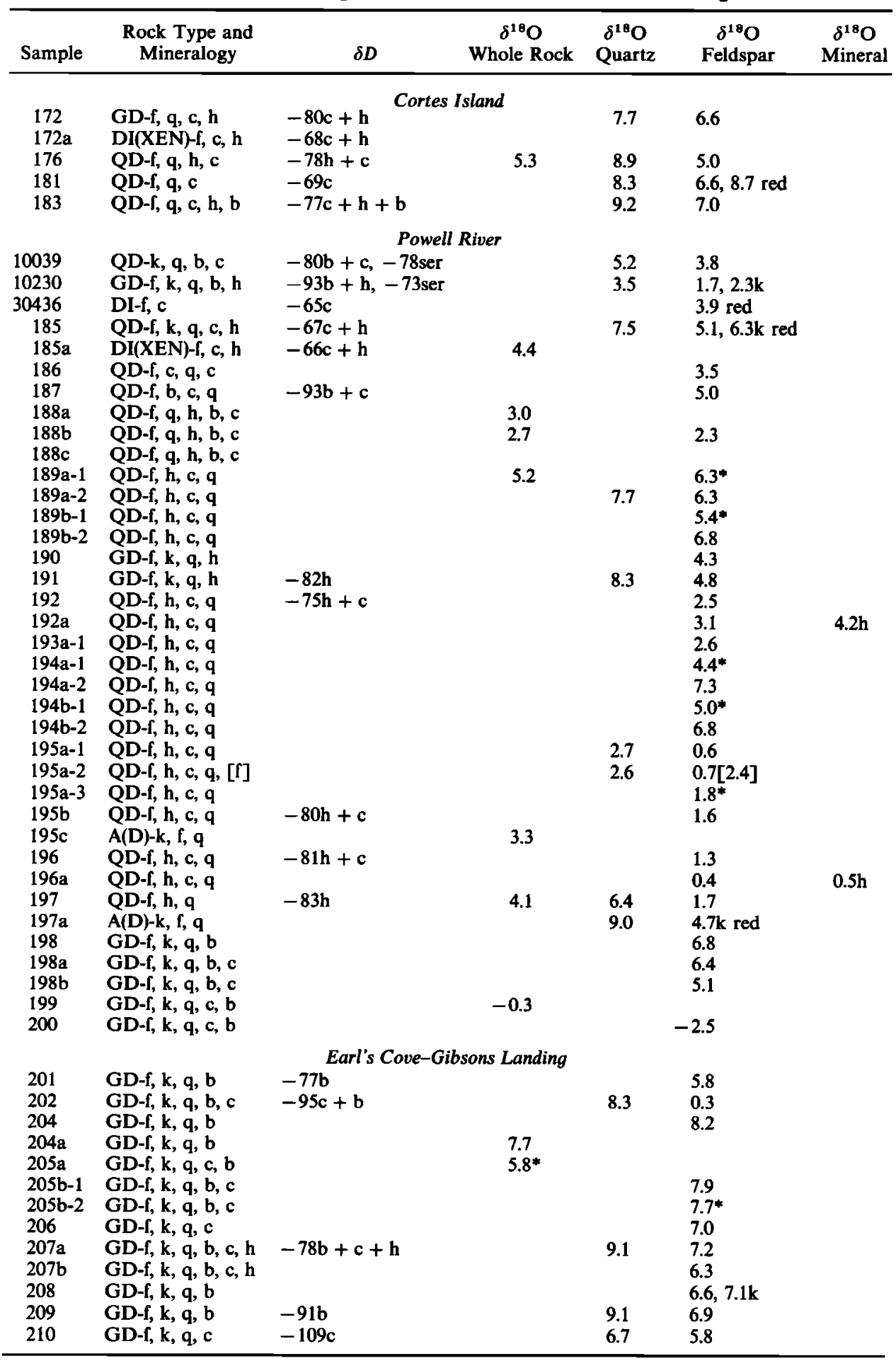

See Table 2 footnote.

*Near vein.

ations where the host rocks had low $\delta^{18} \mathrm{O}$ values, the feldspars near the veins were also found to be similarly low in ${ }^{18} \mathrm{O}$, but in more "normal" ${ }^{18} \mathrm{O}$ outcrops, the feldspars near the veins are consistently $1.5-1.0 \%$ lower in ${ }^{18} \mathrm{O}$ than the feldspars from the bulk rocks. This indicates that the veins and fractures were the conduits for the low- ${ }^{18} \mathrm{O}$ hydrothermal fluids, and it also indicates that where alteration was more pervasive and the water/rock ratios were very high, the ${ }^{18} \mathrm{O}$ depletions were not simply confined to the vicinity of the veins but were spread out over a much larger volume of rock.

Summing up, marked ${ }^{18} \mathrm{O}$ depletions are observed in all samples throughout approximately a 75-km-long traverse along the Coast Highway (Route 101) along the line LundPowell River-Westview-Saltery Bay-Earl's Cove-Sechelt Inlet. These ${ }^{18} \mathrm{O}$ depletions are locally present, but much less important, to the northwest of Lund in the vicinity of Cortes 


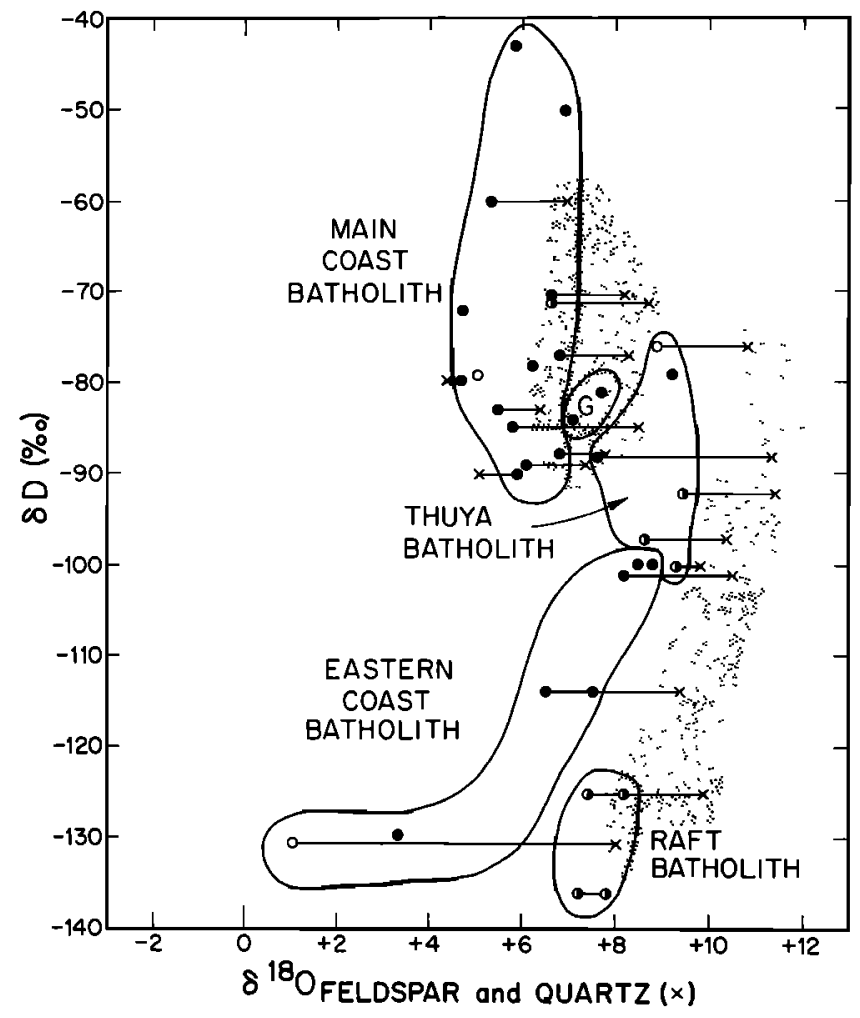

Fig. 4. Plot of $\delta \mathrm{D}$ versus $\delta^{18} \mathrm{O}$ feldspar and quartz for samples of granitic rocks from the Central (Main) Coast Batholith, the Thuya Batholith (Upper Triassic or Lower Jurassic), the Eastern Coast Batholith, and the Raft Batholith. Symbols are the same as on Figure 3.

Island and also throughout most of Sechelt Peninsula and farther south along the line Irvines Landing-Halfmoon BayRoberts Creek-Gibsons Landing-Longdale. However, note that granodiorite sample 10230 from East Redonda Island 30 $\mathrm{km}$ north of Lund also shows a very dramatic ${ }^{18} \mathrm{O}$ depletion, having feldspar $\delta^{18} \mathrm{O}=+1.7$ to +2.3 . This is a typical pluton in this area, implying the existence of a widespread, major hydrothermal event on the mainland of southwestern British Columbia. The only plausible source of such abundant low- ${ }^{18} \mathrm{O}$ hydrothermal fluids is meteoric ground water, and these groundwaters could not have had $\delta \mathrm{D}$ values any lower than about -50 , indicating that they are representative of a warmer, more temperate climate than that presently existing in southern British Columbia.

It is interesting that the chlorites from the Powell RiverCortes Island areas have $\delta \mathrm{D}$ values of -65 to -69 , slightly lower than the -46 to -60 values of chlorites from most of Vancouver Island but significantly higher than the chlorites of the Kennedy Lake area $(-80$ to -94$)$. The only chlorites at all comparable to the Kennedy Lake samples are those from the anomalous sample 210 from Gibsons Landing $(\delta \mathrm{D}=$ -109 ). These isotopic systematics imply that the bulk of the hydrothermal alteration on both Vancouver Island and in the Western Coast Batholith was late Mesozoic in age (probably Late Jurassic to Middle Cretaceous) and that there was a trend inland toward hydrothermal fluids with slightly lower $\delta \mathrm{D}$ and markedly lower $\delta^{18} \mathrm{O}$ values. Later, during the early to mid-Tertiary, lower- $\delta \mathrm{D}$ meteoric fluids locally became important (Kennedy Lake area and possibly sample 210), but this alteration was generally less pervasive and much weaker (lower temperature?) than the earlier one. Some support for these age relationships is given by $\mathrm{K} / \mathrm{Ar}$ ages from the vicinity of the plutons represented by samples 10230 and 10039 (111113 Ma (J. A. Roddick, personal communication, 1985). Note also that the area discussed above lies between the 100 and $140 \mathrm{Ma}$ regional K/Ar age contours [see Parrish, 1983, Figure 2].

The above data indicate that a major structural discontinuity of some type is required to explain the abrupt change in $\delta \mathrm{D}$ and particularly in $\delta^{18} \mathrm{O}$ across the Strait of Georgia. Even though this part of the mainland and Vancouver Island are both regarded as part of Wrangellia, there must have been some major differences in the geologic history of the two regions during and after the emplacement of the granitic plutons in the late Mesozoic. The Western Coast Plutonic Complex was definitely altered by low- ${ }^{18} \mathrm{O}$ meteoric waters at relatively shallow depths in a subaerial (continental?) environment, whereas the early alteration on Vancouver Island probably involved marine pore fluids or formation waters with much higher $\delta^{18} \mathrm{O}$ values. These two phenomena conceivably could have occurred simultaneously in one coherent terrane, but only if the Vancouver Island area was entirely submarine for the duration of the alteration episode while the adjacent mainland terrane was subaerial. It seems most likely that they are in fact juxtaposed terranes with different geologic histories. Our stable isotope data can best be explained if the late Mesozoic subsolidus hydrothermal alteration of the granitic plutons in the Western Coast Plutonic Complex occurred farther south in a coastal (island?) environment. For example, present-day meteoric waters with similar isotopic compositions occur today in the Coast Ranges of northern California and Oregon.

The $\delta^{18} \mathrm{O}$ values of most of the granitic quartz samples from the Western Coast Plutonic Complex plot in the stippled field of Figure 3 and thus are virtually indistinguishable from those on Vancouver Island (Tables 2 and 3). This also means that in both areas the $\delta^{18} \mathrm{O}$ values of the rocks were similar at about +7 to +9 prior to alteration. However, several quartz samples $(195,10039,10230)$ have very low $\delta^{1 B} \mathrm{O}$ values and must either have crystallized from $l o w-{ }^{18} \mathrm{O}$ magmas [see Taylor, 1977] or must have become depleted in ${ }^{18} \mathrm{O}$ along with the leldspar during subsolidus exchange. The latter is very likely in these rocks because the hydrothermal alteration probably occurred at relatively high temperatures and because the rocks are quartz diorites containing only small amounts of very fine grained quartz (which is much more easily exchanged than coarse-grained quartz). This problem is taken up in more detail below in a discussion of Figures 12 and 13.

\section{Coast Plutonic Complex}

\section{Central Coast Batholith}

Figure 4 displays the isotopic data for the main part of the Coast Plutonic Complex. The eastern part of this complex intrudes the Methow-Tyaughton Terrane, but the bulk of the Central Coast Batholith was apparently emplaced into the Tracy Arm and Nooksack terranes [Monger and Berg, 1984]. Although earlier workers [e.g., Coney et al., 1980] included the latter area as part of Wrangellia, the stratigraphy and geologic history of the Nooksack Terrane differ markedly from that of the Wrangellia Terrane [Monger and Berg 1984].

The sampled areas include (1) four samples from the Mount Grenville area, located $20-40 \mathrm{~km}$ east of the head of Bute Inlet, (2) three widely scattered samples located between the upper reaches of Toba Inlet and the head of Jervis Inlet, and (3) a densely sampled traverse across the entire plutonic complex along Highway 99 from Horseshoe Bay and Squamish on 
Table 4. Oxygen and Hydrogen Isotope Analyses of Minerals and Rocks From the Central Coast Batholith (10,000 Series Samples) and From a SW-NE Traverse Across the Batholith Along the Line Horsehoe Bay-Squamish-Pemberton-Lillooet (Samples 227 to 270)

\begin{tabular}{|c|c|c|c|c|c|}
\hline Sample & $\begin{array}{l}\text { Rock Type and } \\
\text { Mineralogy }\end{array}$ & $\delta D$ & $\begin{array}{c}\delta^{18} \mathrm{O} \\
\text { Whole Rock }\end{array}$ & $\begin{array}{l}\delta^{18} \mathrm{O} \\
\text { Quartz }\end{array}$ & $\begin{array}{c}\delta^{18} \mathrm{O} \\
\text { Feldspar }\end{array}$ \\
\hline $\begin{array}{l}10432 \\
10430 \\
10405 \\
40007\end{array}$ & $\begin{array}{l}\text { GD- } k, f, q, b, h \\
\text { QD- } f, k, q, b, h \\
\text { GD- } f, k, q, b, h, c \\
\text { QD- } f, g, h, b\end{array}$ & $\begin{array}{l}\text { Central Coast Batholith } \\
-83+h \\
-80 b+h,-80 \text { ser } \\
-71 b+h+c,-96 \mathrm{ser} \\
-88 h+b\end{array}$ & Vorth) & $\begin{array}{l}6.4 \\
4.4 \\
8.2 \\
7.8\end{array}$ & $\begin{array}{l}5.5 \\
4.7 \\
6.6 \\
6.8\end{array}$ \\
\hline $\begin{array}{l}10018 \\
10267 \\
10291 \\
10291 \mathrm{MZ}\end{array}$ & 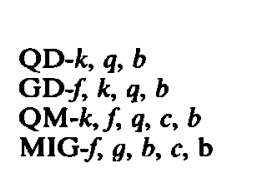 & $\begin{array}{l}\text { Central Coast Batholith } \\
-90 b,-83 \mathrm{ser} \\
-77 b,-92 \mathrm{ser} \\
-71 c+b \\
-80 c+h\end{array}$ & West) & $\begin{array}{l}5.1 \\
8.3 \\
8.7\end{array}$ & $\begin{array}{l}5.9 \\
6.8 \\
6.6\end{array}$ \\
\hline $\begin{array}{l}227 \\
228 \\
228-1 \\
228-2 \\
228-3 \\
228-4 \\
228-4 \\
229 \\
229 a \\
229-1\end{array}$ & $\begin{array}{l}\text { GD-f, } k, q, b, c \\
\text { QD-f, } b, c, q \\
\text { QM-f, } k, q \\
\text { PO(D)-f, } k, q, c \\
\text { PO(D)-f,k, } q, c \\
\text { BA(D)-f, } a,[e, q] \\
\text { PO[XEN]-f, } q, c \\
\text { QD-f,c, } h, q,[e, q] \\
\text { (V)-[e, } q, c, f] \\
\text { PEG-q, } k, f,[q]\end{array}$ & $\begin{array}{l}\quad \text { Squamish Area } \\
-60 b+c \\
-73 b \\
-73 c \\
-95 a,[-40 e] \\
-80 c \\
-80 c+h,[-67 e] \\
\quad[-68 e]\end{array}$ & 4.2 & $\begin{array}{l}{[7.6]} \\
{[6.5]} \\
{[6.0]}\end{array}$ & $\begin{array}{l}5.3 \\
6.0 k \text { red } \\
4.0 \\
5.0 \\
3.0 \\
{[4.1]} \\
3.6\end{array}$ \\
\hline $\begin{array}{l}236 \\
236 a \\
242 \\
246 \\
247 \\
247 a \\
249 \\
251 \\
252 \\
254 \\
256 \\
257\end{array}$ & $\begin{array}{l}\text { QM-f, } k, q, b, c \\
\text { QM-f, } k, q, b, c \\
\text { BA-f, } a, c \\
\text { BA-f, } c \\
\text { QD-f, } h, c, q \\
\text { DI(XEN)-f, } h, q \\
\text { BA-f, } c, e,[q, e] \\
\text { GD-f, } k, q, b \\
\text { GD- } f, k, q, b, c \\
\text { GD-f, } k, q, h, b \\
\text { BA-f, } a \\
\text { SCH- } q, m\end{array}$ & $\begin{array}{l}\text { Central Coast Batholith (S } \\
\quad-89 b+c \\
-57 a+c \\
-85 c \\
-43 h+c \\
-50 h \\
-71 c+e,[-81 e] \\
-78 b \\
-85 b+c \\
-72 h+b \\
-84 a \\
-73 m\end{array}$ & $\begin{array}{l}4.6 \\
4.7 \\
\\
5.7 \\
7.6 \\
\end{array}$ & $\begin{array}{l}7.4 \\
7.0\end{array}$ & $\begin{array}{l}5.8 \\
6.9 \\
\\
6.2 \\
5.8 \\
4.7\end{array}$ \\
\hline $\begin{array}{l}260 \\
261 \\
262 \\
263 \\
264 \\
265 \\
266 \\
268 \\
269 \\
270 \\
270 a\end{array}$ & $\begin{array}{l}\text { MIG-f, } a \\
\text { PO } \\
\text { SCH } \\
\text { GD-f, } k, q, b \\
\text { QD- } q, f, k, b \\
\text { SCH- } q, f, m, c \\
\text { SCH } \\
\text { PO } \\
\text { GD- } f, k, q, b, c \\
\text { GN- } f, k, q, b, c \\
\text { GN-f, } k, q, c, b\end{array}$ & $\begin{array}{l}\quad \text { Eastern Coast Batho } \\
-100 a \\
-111 c \\
-73 c \\
-101 b \\
-100 b \\
-70 c+m \\
-69 c+b \\
-114 c \\
-114 b+c \\
-130 b+c\end{array}$ & $\begin{array}{l}12.5 \\
13.6 \\
10.9\end{array}$ & $\begin{array}{l}9.4 \\
8.0 \mathrm{HF}\end{array}$ & $\begin{array}{l}7.5,6.5 k \mathrm{red} \\
3.3 \\
1.0\end{array}$ \\
\hline
\end{tabular}

See Table 2 footnote. The 10,000 series samples are described by Woodsworth [1980].

the southwest to Garibaldi and D'Arcy on the northeast (Table 4).

The granitic rocks from the main part of the Coast Batholith have relatively low and uniform $\delta^{\mathbf{1 8}} \mathrm{O}$ feldspar values $(+4.5$ to +6.7$)$, and except for two samples with $\delta \mathrm{D}=-43$ and -60 they also have remarkably uniform $\delta \mathrm{D}$ values $(-70$ to -90 ), very similar to primary magmatic deuterium concentrations in most igneous and metamorphic rocks throughout the world [Taylor, 1974b]. These isotopic compositions are also similar to the Cortes Island samples and to some other samples from the Western Coast Batholith (Figure 3). However, the samples from the interior are characteristically much less chloritized than the coastal samples, and these interior samples also are all much higher in ${ }^{18} \mathrm{O}$ than the Powell River samples described in the previous section (Figure 3).

No samples with extreme ${ }^{18} \mathrm{O}$ depletion have been found in the Central Coast Batholith, indicating a lack of any large- scale meteoric-hydrothermal alteration. This is compatible with relativly deep emplacement of these plutons and with the data of Parrish [1983], who has shown that this entire area has undergone about $4 \mathrm{~km}$ of uplift in just the last $10 \mathrm{~m} . \mathrm{y}$. alone. Only four of the analyzed samples have anomalous $\delta^{18} \mathrm{O}$ values, 229, 10430, 10432, and 10018; the first of these is heavily chloritized and epidotized and riddled with quartz veins $\left(\delta^{18} \mathrm{O}\right.$ vein quartz $\left.=6.0-6.8\right)$, and the other three are from relatively old plutons that were metamorphosed when some of the large, younger plutons were emplaced (G. J. Woodsworth, personal communication, 1976). For example, the Sisyphus Creek (10432) and Ixion (10430) plutons were metamorphosed at about $72 \mathrm{Ma}$ by the Mount Gilbert pluton (40007). The Bishop River pluton (10405) was emplaced even later at about $55 \mathrm{Ma}$. Note that all of the altered samples have unusually low- ${ }^{18} \mathrm{O}$ quartz; also, two of these samples strongly differ from most samples that have undergone meteoric- 
hydrothermal alteration in that the $\delta^{18} \mathrm{O}$ of coexisting feldspar is higher than the $\delta^{18} \mathrm{O}$ of the quartz. These rocks must have either crystallized from low- ${ }^{18} \mathrm{O}$ magmas or they must have undergone intense hydrothermal exchange at temperatures sufficiently high to strongly affect the quartz. Subsequently, their feldspars were enriched in ${ }^{18} \mathrm{O}$ by at least $1-2 \%$ or more, probably by some type of low-temperature hydrothermal event.

Except for the anomalous (hydrothermally metamorphosed?) samples discussed above, the $\delta^{\mathbf{1 8}} \mathrm{O}$ values of quartz are very uniform at +7.0 to +8.5 (upper stippled pattern on Figure 4). Also, the $\Delta^{18} \mathrm{O}$ quartz-feldspar values lie in the range $0.9-2.7$, within the "normal" range exhibited by fresh, unaltered plutonic igneous rocks throughout the world. In particular, note that sample 10267 is from one of the largest single plutons in the Coast Mountains and has a $\mathrm{K} / \mathrm{Ar}$ age of $82 \mathrm{Ma}$. This giant pluton is isotopically almost identical to sample 10291, the light-colored portion of a typical migmatite sample from the Central Gneiss Complex. These data clearly imply that these Central Coast Batholith samples crystallized with primary whole-rock $\delta^{18} \mathrm{O}$ values of +5.5 to +7.0 , considerably lower than those from any other terrane in British Columbia discussed in this paper but very similar to the range exhibited by most basalts and many island arc andesites from areas where there has been little or no involvement with continental crust. This range of $\delta^{18} \mathrm{O}$ is also identical to that observed by Taylor and Silver [1978] for plutons from the western side of the Peninsular Ranges Batholith of southern and Baja California.

Summing up, in the plutonic granitic rocks of southern British Columbia, we see a fairly dramatic change in both the primary $\delta^{18} \mathrm{O}$ values and in the subsolidus hydrothermal effects approximately coinciding with the Wrangellia-Nooksack terrane boundary, as defined by Monger and Berg [1984]. The eastern edge of the Wrangellia Terrane (Powell River traverse) exhibits "old" $\mathrm{K} / \mathrm{Ar}$ ages $(100-140 \mathrm{Ma})$ and is the site of intense and pervasive meteoric-hydrothermal activity, but this activity terminates fairly abruptly as one moves eastward into the Nooksack Terrane and into the Central Coast Batholith, where the $\mathrm{K} / \mathrm{Ar}$ ages are much younger and where the amount of late Tertiary uplift and erosion has been much greater. In addition, although the effects are partially obscured by the hydrothermal activity, the calculated primary magmatic whole-rock $\delta^{18} \mathrm{O}$ values of the granitic plutons in the Wrangellia Terrane are distinctly higher than in the Nooksack Terrane (see Table 8 below).

\section{Eastern Coast Batholith}

As defined in this paper, the Eastern Coast Batholith includes a group of smaller, more isolated plutons along the eastern edge of the Coast Plutonic Complex; the samples studied by us were all emplaced into the Bridge River Terrane [Monger and Berg, 1984]. As shown in Table 4 and Figure 4, there is a pronounced change in both $\delta \mathrm{D}$ and $\delta^{18} \mathrm{O}$ as one crosses from the Central Coast Batholith into the Bridge River Terrane. In our progressive eastward movement across southern British Columbia, this zone provides the first evidence for some very low $\delta \mathrm{D}$ values, down to values as low as -130 . Together with $\delta^{18} \mathrm{O}$ feldspar values as low as +1.0 in sample $270 \mathrm{a}$, these low $\delta \mathrm{D}$ values require the involvement of low- $\delta \mathrm{D}$, low- $\delta^{18} \mathrm{O}$ meteoric-hydrothermal fluids along the eastern edge of the Coast Batholith. This was not a surprise because a similar phenomenon on an even larger scale was observed by us [Magaritz and Taylor, 1976a] at the eastern edge of the Coast Plutonic Complex farther north along the Prince Rupert-Prince George traverse in the vicinity of the Ponder pluton (see Figures 14 and 15 below). Note on Figure 4 the development of the typical "inverted-L" pattern that is characteristic of $\delta \mathrm{D}-\delta^{18} \mathrm{O}$ diagrams for rocks that have undergone meteoric-hydrothermal alteration [Taylor, 1977].

The $\delta^{18} \mathrm{O}$ quartz values of three samples of granitic rocks from the Eastern Coast Batholith are $+8.0,+9.4$, and +10.5 , implying primary $\delta^{\mathbf{1 8}} \mathrm{O}$ whole-rock values of about +7.5 to +9.5 , distinctly higher than the +6 to +7 values characteristic of the Central Coast Batholith (Table 4, Figure 4).

We also analyzed several of the mica schists that are abundant along the eastern edge of the Coast Batholith. Typical of such rocks elsewhere, these have relatively high whole-rock $\delta^{18} \mathrm{O}$ values, +12.5 to +21.9 , and the $\delta \mathrm{D}$ values are very uniform at -69 to -73 (Table 4). Apparently, the meteorichydrothermal alteration effects associated with the granitic plutons are very weak in this area and do not extend any appreciable distance outward into the metamorphic country rocks. This contrasts strongly with the effects observed farther north in the area east of the Ponder pluton, where the metasedimentary rocks have been pervasively altered by meteorichydrothermal fluids [Magaritz and Taylor, 1976a]. It seems apparent that this northern traverse (see Figures 14 and 15 below) must be sampling either more permeable country rocks or a much shallower erosion level than the traverse from D'Arcy to Lillooet in the present study.

\section{Guichon, ThuYa, and Raft Batholiths}

\section{General Statement}

Proceeding eastward along the same line of traverse described in the previous section, we encounter an extensive area where plutons are rare or absent; this is termed the Cache Creek Terrane [Monger et al., 1982; Monger and Berg, 1984]. However, once we cross the Cache Creek Terrane and enter the so-called Quesnel Terrane, plutonic granitic rocks again become relatively abundant, although the concentration of plutons is much lower than in the Coast Plutonic Complex.

Some of the relatively isolated batholiths in the Quesnel Terrane are unique in having retained very old $\mathrm{K} / \mathrm{Ar}$ ages. For example, both the Guichon and the Thuya batholiths have preserved 190-200 Ma K/Ar ages indicative of emplacement in the Upper Triassic or lowermost Jurassic. The K/Ar ages of these batholiths seem to have largely escaped "resetting," probably because there was little or no late Mesozoic or Tertiary plutonism in the immediate vicinity. In these areas, we thus have a chance to observe the isotopic systematics in some early Mesozoic plutons without having to "look through" a complex later history of plutonism and hydrothermal alteration.

\section{Thuya Batholith}

The $\delta^{18} \mathrm{O}$ and $\delta \mathrm{D}$ data for the Thuya Batholith are shown in Figure 4 and Table 5. The $\delta \mathrm{D}$ values of chlorite, biotite and hornblende are relatively uniform at -76 to -100 , only slightly lower than the accepted values of primary magmatic biotites and hornblendes throughout the world. The $\Delta^{18} \mathrm{O}$ quartz-feldspar values are also very uniform and "normal" (1.4-2.0). Most of the samples are chloritized, however, so they must have suffered a moderate degree of hydrothermal alteration. Nonetheless, it is clear that this cannot be a late Mesozoic or Cenozoic alteration event because of the lack of any indication of the characteristic low $\delta \mathrm{D}$ values such as are found just to the northeast in the Raft Batholith, to the west in the Eastern Coast Batholith, or to the south in the Okanagan Batholith. Thus the $\delta \mathrm{D}$ data are in good agreement with the geological and K/Ar age data that the Thuya Batholith under- 
TABLE 5. Oxygen, Hydrogen, and Carbon Isotope Analyses of Minerals and Rocks From the Thuya, Raft, and Guichon Batholiths and From the Area Between the Coast and Okanagan Batholiths (Princeton Area)

\begin{tabular}{|c|c|c|c|c|c|c|c|}
\hline Sample & $\begin{array}{l}\text { Rock Type } \\
\text { and } \\
\text { Mineralogy }\end{array}$ & $\delta D$ & $\begin{array}{l}\delta^{18} O \\
\text { Whole } \\
\text { Rock }\end{array}$ & $\begin{array}{l}\delta^{18} \mathrm{O} \\
\text { Quartz }\end{array}$ & $\begin{array}{c}\delta^{18} \mathrm{O} \\
\text { Feldspar }\end{array}$ & $\begin{array}{c}\delta^{18} \mathrm{O} \\
\text { Mineral }\end{array}$ & $\begin{array}{c}\delta^{13} \mathrm{C} \\
\text { Carbonate }\end{array}$ \\
\hline \multicolumn{8}{|c|}{ Bonaparte Lake Map Sheet } \\
\hline $\begin{array}{l}86 \\
87 \\
88 \\
89 \\
90 \\
91\end{array}$ & $\begin{array}{l}\text { GD- } f, k, q, c, h \\
\text { GD- } f, k, q, c, h \\
\text { DI- } f, q, c, b, h \\
\text { GD- } f, k, q, b, h \\
\text { GD- } f, k, q, c, e, a \\
\text { DI- } f, q, h, c\end{array}$ & $\begin{array}{l}\quad \text { Thuya Batholit } \\
-100 c+h,-101 \text { ser } \\
-92 c+h \\
-97 c+b+h \\
-88 b+h \\
-76 c+e+a \\
-79 h+c\end{array}$ & $\begin{array}{l}\text { ith (Tria } \\
8.5 \\
9.4 \\
9.1 \\
9.1 \\
8.8 \\
7.3\end{array}$ & $\begin{array}{r}\text { assic) } \\
9.8 \\
11.4 \\
10.4 \\
11.3 \\
10.8\end{array}$ & $\begin{array}{l}9.3,8.4 k \\
9.4 \\
8.6 \\
7.6 \\
8.9 \\
9.2\end{array}$ & $\begin{array}{l}4.7 b, 7.2 h \\
5.2 b, 6.0 h \\
5.5 c \\
6.5 h\end{array}$ & \\
\hline $\begin{array}{l}95 \\
96\end{array}$ & $\begin{array}{l}\mathrm{QM}-f, k, q, b, c \\
\mathrm{QM}-f, k, q, b, c\end{array}$ & $\begin{array}{c}\text { Raft Batholith (L } \\
-125 b+c \\
-136 b+c\end{array}$ & $\begin{array}{l}\text { ate Cret } \\
8.2 \\
8.5\end{array}$ & $\begin{array}{l}\text { taceous) } \\
9.9\end{array}$ & $\begin{array}{l}7.4,8.2 k \\
7.8,7.2 k\end{array}$ & $1.0 b$ & \\
\hline $\begin{array}{l}275 \\
277-1 \\
278 \\
281\end{array}$ & 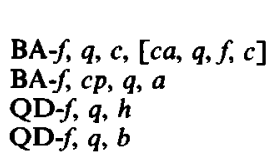 & $\begin{array}{l}\quad \text { Guichon Bathol } \\
-57 c,[-55 c] \\
-82 a \\
-84 h \\
-81 b\end{array}$ & $\begin{array}{c}\text { lith (Tri } \\
7.3 \\
7.5\end{array}$ & iassic) & $\begin{array}{l}7.1 \\
7.7\end{array}$ & {$[4.0 c, 9.8 c a]$} & {$[-6.1 c a]$} \\
\hline $\begin{array}{l}282 \\
283 \\
285 \\
286\end{array}$ & $\begin{array}{l}\text { BA-f, } c p, c, a \\
\text { BA-f, } q, c a, c \\
\text { QD-f, } k, q, h \\
\text { DI-f, } h\end{array}$ & $\begin{array}{l}-129 c+a \\
-78 c \\
-93 h \\
-107 h\end{array}$ & $\begin{array}{c}\text { Area } \\
5.7\end{array}$ & & $\begin{array}{r}6.5 \\
-1.1\end{array}$ & $9.3 \mathrm{ca}$ & $-0.1 c a$ \\
\hline
\end{tabular}

See Table 2 footnote.

went a much earlier (Triassic?) emplacement and alteration event that probably involved heated formation waters or relatively deuterium-rich meteoric groundwaters. Taken together, the isotopic and age data suggest that (1) the geographic position of this terrane was much farther south at that time, and/or (2) the early Mesozoic climate in this region was much warmer than it was in the Cenozoic or during the present day.

The $\delta^{18} \mathrm{O}$ quartz values in the Thuya Batholith range from +9.8 to +11.4 , slightly higher than in the Eastern Coast Batholith. This continues the pattern of increasing whole-rock $\delta^{18} \mathrm{O}$ values in the granitic rocks as one moves eastward from the main part of the Coast Plutonic Complex.

\section{Raft Batholith}

The mid-Cretaceous Raft Batholith is located only $30 \mathrm{~km}$ north of the Triassic Thuya granitic rocks described above. However, the Raft Batholith has much different $\delta \mathrm{D}$ values and $\delta^{18} \mathrm{O}$ feldspar and $\delta^{18} \mathrm{O}$ biotite values than the Thuya Batholith (Table 5) and was obviously altered by drastically different hydrothermal fluids. The $\delta \mathrm{D}$ values of these fluids were apparently slightly lower than those that affected the Eastern Coast Batholith, but by no more than 5-10\%.

The Raft plutons also in part occupy a separate terrane, the so-called Slide Mountain Terrane (Figure 2). Nevertheless, the single $\delta^{18} \mathrm{O}$ quartz analysis from the Raft Batholith $(+9.9)$ is within the range of $\delta^{18} \mathrm{O}$ quartz observed in the Thuya Batholith. Thus granitic magmas with similar $\delta^{18} \mathrm{O}$ values were emplaced in this geographic area at widely separated times during the Mesozoic.

\section{Guichon Batholith}

Although it is somewhat unique in that it contains a major porphyry copper ore deposit, the Guichon Batholith shares many characteristics in common with the Thuya Batholith.
Among these are its size, geographic location, geologic setting, and its Early Mesozoic emplacement age. Not surprisingly, the $\delta^{18} \mathrm{O}$ and $\delta \mathrm{D}$ values are also virtually identical to those of the Thuya Batholith (Figure 4, Table 5). No evidence was found for any $\delta \mathrm{D}$ values lower than -84 , either in the tonalite plutons or in the country-rock basalts (Table 5). Thus the late Mesozoic and Cenozoic meteoric-hydrothermal activity that was so prominent in the surrounding batholiths (see below) seems to be totally missing here, in keeping with the preservation of the ancient $\mathrm{K} / \mathrm{Ar}$ ages.

\section{Okanagan (Similkameen) Batholith}

\section{General Statement}

The Okanagan Batholith, referred to also by several other names (see discussion by Peto [1975] and Medford et al. [1983]) is a concentrically zoned, composite batholith that is dominantly mid-Jurassic in age (183-151 Ma [Peto, 1973; Peto and Armstrong, 1976]). It consists marginally of older quartz diorites and centrally of younger granodorites and quartz monzonites (Figure 2). The batholith was in part emplaced at relatively shallow depths, and it intrudes the Triassic Nicola Group in the west and the Shuswap metamorphic complex in the east [Peto, 1973].

Four samples were collected near Princeton, British Columbia, between the Lytton and Okanagan Batholiths (two basalts, a tonalite, and a diorite). These data are shown in Figure 5 and Table 6. It is clear that some moderately low- $\delta \mathrm{D}$ meteoric-hydrothermal alteration occurred in this region $(\delta \mathrm{D}$ as low as -107 in the diorite pluton and -129 in the basalt), very similar to what is observed in the Eastern Coast Batholith. The isotopic characteristics of the two plutonic rocks are indicated on Figure 5 by the small "inverted-L" pattern. 


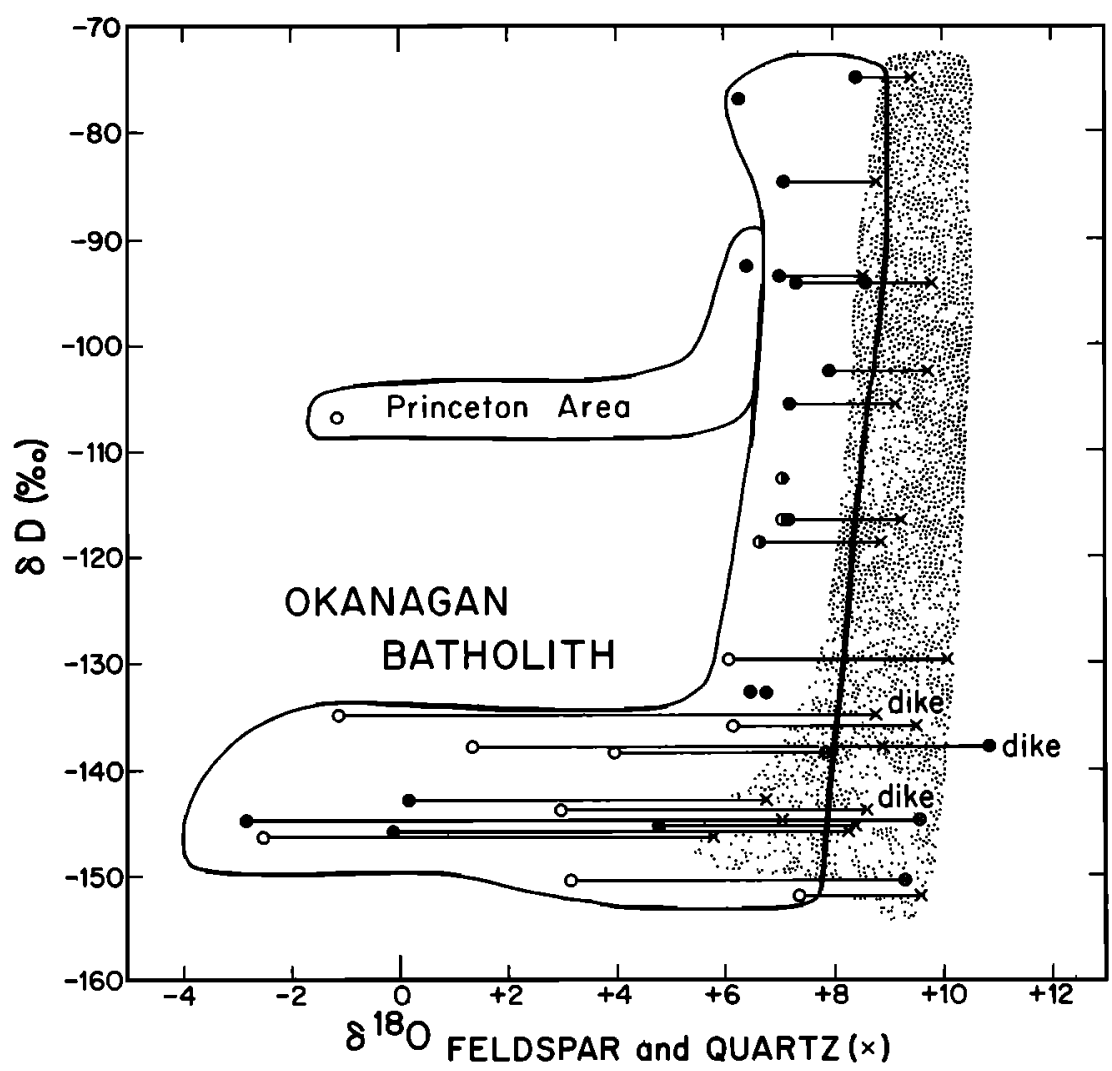

Fig. 5. Plot of $\delta \mathrm{D}$ versus $\delta^{18} \mathrm{O}$ feldspar and quartz for samples of granitic rocks from the Okanagan Batholith, including two samples farther to the west (Princeton area). Symbols are the same as on Figures 3 and 4, except that the encircled crosses indicate HF-treated quartz.

\section{Central Okanagan Batholith}

Several samples from the main part of the Okanagan Batholith were collected along the traverse PrincetonJellicoe-Trout Creek-Summerland (Table 6). Although a few samples of plutonic granitic rocks along this traverse have both normal $\delta \mathrm{D}$ and normal $\delta^{1 \mathrm{~B}} \mathrm{O}$ values (samples 291, 293, 302), most of the samples have undergone a modest degree of meteoric-hydrothermal alteration, as evidenced by the striking deuterium depletions ( $\delta \mathrm{D}=-94$ to -138 ), together with negligible or minor $\delta^{18} \mathrm{O}$ depletions. The samples from this traverse are largely confined to the vertical arm of the large "inverted- $L$ " data point envelope in Figure 5.

Where measureable ${ }^{18} \mathrm{O}$ depletions are observed in the feldspars (samples 294, 295, 296), they are invariably associated with very low $\delta \mathrm{D}$ values of -133 to -138 and the imprint of a reddish coloration in the alkali feldspars. Also, in two out of three cases, they are also associated with complete chloritization of the primary mafic minerals.

\section{Okanagan Lake Traverse}

A suite of samples was collected from the Okanagan Batholith along virtually the entire length of Okanagan Lake (Figure 2). This suite of samples differs dramatically from the samples described above from the main part of this batholith. Each and every sample from the Okanagan Lake traverse is markedly depleted in deuterium, with values typically in the range -130 to -154 . Thus, in our progression eastward from Vancouver Island these are by far the lowest $\delta \mathrm{D}$ values yet encountered in any granitic plutons. Most of the granitic rocks also exhibit strong ${ }^{18} \mathrm{O}$ depletions $\left(\delta^{18} \mathrm{O}\right.$ feldspar $=$ -2.8 to +6.7 in samples collected right along the edge of
Okanagan Lake), and the bulk of the samples thus lie within the horizontal arm of the "inverted-L" pattern shown in Figure 5.

Along this traverse through the eastern part of the Okanagan Batholith, the Mesozoic plutons are intruded by several much younger porphyry stocks and dikes (the Tertiary Coryell intrusions and associated Princeton volcanics). All of the rocks from the Okanagan Lake traverse have been intensely chloritized; it seems likely that hydrothermal systems associated with the Tertiary porphyries are responsible for the ${ }^{18} \mathrm{O}$ and deuterium depletions, as well as the strong chloritization, because at a given locality, the dikes and porphyries consistently have lower $\delta^{18} \mathrm{O}$ values than the granitic country rocks that they intrude. Also, samples of the same plutonic unit (Valhalla granodiorite) have "normal" $\delta^{18} \mathrm{O}$ values in the center of the batholith, but at the eastern margin where this unit is intruded by the Tertiary porphyries, the feldspars and biotites all show much lower $\delta^{18} \mathrm{O}$ values. Samples 108 and 110 have wholerock $\delta^{18} \mathrm{O}$ of +0.2 and +1.1 and feldspar $\delta^{18} \mathrm{O}$ of -2.8 and -0.1 , respectively. A quartz separate from sample 108 was "stripped" by the partial fluorination method described by Magaritz and Taylor [1976a]; the strong ${ }^{18} \mathrm{O} /{ }^{16} \mathrm{O}$ zoning in these quartz grains is described below and illustrated in Figure 12. The Valhalla pluton clearly interacted with large amounts of low- ${ }^{18} \mathrm{O}$, meteoric-hydrothermal fluids under subsolidus conditions $\left(\sim 300^{\circ}-400^{\circ} \mathrm{C}\right)$.

The dramatically larger ${ }^{18} \mathrm{O} /{ }^{16} \mathrm{O}$ effects observed in the Okanagan Batholith in the vicinity of Okanagan Lake are almost certainly due in large part to the abundant Tertiary dikes and stocks that occur near this lineament. However, Okanagan Lake also probably occupies a major fracture zone, providing for enhanced permeability that would allow much 
TABLE 6. Oxygen, Hydrogen, and Carbon Isotope Analyses of Rocks and Minerals From the Okanagan (Similkameen) Batholith

\begin{tabular}{|c|c|c|c|c|c|c|c|}
\hline Sample & $\begin{array}{l}\text { Rock Type } \\
\text { and } \\
\text { Mineralogy }\end{array}$ & $\delta D$ & $\begin{array}{l}\delta^{18} \mathrm{O} \\
\text { Whole } \\
\text { Rock }\end{array}$ & $\begin{array}{c}\delta^{18} \mathrm{O} \\
\text { Quartz }\end{array}$ & $\begin{array}{c}\delta^{18} \mathrm{O} \\
\text { Feldspar }\end{array}$ & $\begin{array}{c}\delta^{18} \mathrm{O} \\
\text { Mineral }\end{array}$ & $\begin{array}{c}\delta^{13} \mathrm{C} \\
\text { Carbonate }\end{array}$ \\
\hline \multicolumn{8}{|c|}{ Okanagan Lake Traverse } \\
\hline 103 & GD- $f, k, q, b, c$ & $-146 b+c,-102 \mathrm{ser}$ & 4.9 & 8.4 & $4.8 k$ & $5.0 b$ & \\
\hline 104 & $\mathrm{~A}(\mathrm{D})-f, k, c$ & $-135 c$ & 2.3 & 8.3 & $-1.1 k$ & & \\
\hline 105 & $\mathrm{GN}-f, q, c, c a$ & $-144 c$ & 6.2 & & & $+2.2 c a$ & $-6.8 c a$ \\
\hline $105-1$ & $\mathrm{~A}(\mathrm{D})-f, q, c, h$ & $-138 c+h$ & 2.9 & $8.9,10.9 \mathrm{HF}$ & 1.4 & & \\
\hline 106 & $\mathrm{PO}-f, q, k, b$ & $-143 b$ & 3.7 & 6.8 & 0.2 & $3.5 b$ & \\
\hline 108 & GD- $f, k, q, h, c$ & $-145 h+c,-120$ ser & 0.2 & $7.1,9.6 \mathrm{HF}$ & -2.8 & & \\
\hline 110 & GD $f, q, b$ & $-146 b$ & 1.1 & 8.3 & -0.1 & $-1.6 b$ & \\
\hline $110 a$ & $\mathrm{~A}(\mathrm{D})-f, q, c$ & $-144 c$ & 6.0 & 8.6 & 3.3 & & \\
\hline 111 & GD- $f, q, k, c, h$ & $-151 c+h$ & 1.4 & $9.3 \mathrm{HF}$ & 3.2 & & \\
\hline $111-1$ & $\mathrm{PO}-f, q, c$ & $-146 c$ & 0.6 & 5.8 & -2.5 & & \\
\hline 112 & (V) $-[e, f, c a]$ & {$[-108 e]$} & & & {$[5.6]$} & {$[6.0 \mathrm{ca}]$} & {$[-6.2 c a]$} \\
\hline 113 & GD $f, k, q, c, h, b$ & $-119 c+h+b$ & 7.5 & 8.9 & 6.7 & $3.0 b, 6.0 h$ & \\
\hline 304 & QD- $f, q, c$ & $-154 c$ & & 9.6 & 7.4 & & \\
\hline $304 a$ & DI(XEN)-f, $h$ & $-105 h$ & 6.4 & & & & \\
\hline 305 & QD- $f, k, c, h, b$ & $-113 c+h$ & & & 7.1 & & \\
\hline $305 a$ & $\mathrm{~A}(\mathrm{D})-q, k$ & & 9.1 & & 8.5 & & \\
\hline 306 & QD- $f, q, h, b, c$ & $-103 h$ & & 9.8 & 8.0 & & \\
\hline 307 & PO- $q, f, k, c p, c$ & $-130 c$ & & 10.1 & 6.1 & & \\
\hline \multicolumn{8}{|c|}{ Central Part of Okanagan Batholith } \\
\hline 291 & GD- $f, k, q, b, h$ & $-77 b+h$ & & & $6.4,7.5 k$ & & \\
\hline 292 & GD-f, $k, a, b, h$ & $-106 b=h$ & & 9.2 & $7.3,7.3 k$ & & \\
\hline 293 & $\mathrm{QM}-\int, k, q, b$ & $-85 b$ & & 8.9 & $6.7,7.0 k$ & & \\
\hline 294 & GD- $f, k, q, b$ & $-133 b$ & & & $6.5 k$ red & & \\
\hline 295 & GRN- $k, f, q, c$ & $-138 c$ & & 7.9HF & $4.0 k$ red & & \\
\hline 296 & $\mathrm{QM}-q, k, f, c$ & $-136 c$ & & 9.5 & $6.2 k$ red & & \\
\hline 297 & GD- $k, f, q, c, b, h$ & $-117 c+b$ & & 9.3 & $7.2,7.2 k$ & & \\
\hline $297 a$ & $\mathrm{~A}(\mathrm{D})-q, k, f$ & -84 & 8.6 & & & & \\
\hline 298 & $\mathrm{GD}-k, f, q, b$ & $-94 b$ & & 8.6 & $7.1,6.3 k$ & & \\
\hline 301 & QD- $q, k, f, h, c$ & $-94 h+c$ & & 9.9 & $8.6,7.4 k$ & & \\
\hline 302 & QD- $f, q, b$ & $-74 b$ & & 9.9 & 8.6 & & \\
\hline
\end{tabular}

See Table 2 footnote.

greater circulation of surface waters to great depths. In fact, this zone of weakness (rift?) may also have provided the access routes followed by the Tertiary magmas that were the immediate cause of the large-scale hydrothermal alteration that is so prominent in the vicinity of this topographic depression.

\section{Primary Magmatic ${ }^{18} \mathrm{O} /{ }^{16} \mathrm{O}$ Ratios}

The stippled region on Figure 5 illustrates the uniformity of $\delta^{18} \mathrm{O}$ quartz in the Okanagan Batholith. The quartz $\delta^{18} \mathrm{O}$ values vary only from +7.9 to +9.9 if we exclude the porphyries and the heavily altered granodiorite sample 108 . Some of these $\delta^{18} \mathrm{O}$ quartz values have probably been lowered by hydrothermal alteration, as shown by the " $F_{2}$-stripped" quartz grains in sample 108 , the cores of which have $\delta^{18} \mathrm{O} \approx$ +10.0 (Figure 12). This value is slightly higher than the characteristic range shown by even the least altered plutons in the Okanagan Batholith.

Based upon inferences from the $\delta^{18} \mathrm{O}$ quartz values shown in Table 6 , the range of whole-rock $\delta^{18} \mathrm{O}$ in the Okanagan Batholith is estimated to be about +7.5 to +9.0 . This is similar to the range displayed by the Eastern Coast Batholith and only slightly lower than that observed in the Thuya and Raft batholiths.

\section{NeLson Batholith}

\section{Hydrothermal Alteration}

The Nelson Batholith [Rice, 1941; Little, 1960; Archibald et al., 1983, 1984] is a composite batholith, dominantly Mesozoic in age, whose southwestern portion is intruded by a group of Tertiary plutons (Coryell intrusions). These are the same types of intrusions that were responsible for large-scale meteorichydrothermal alteration to the west along the Okanagan Lake section of the Okanagan Batholith. Thus it should come as no surprise that these Tertiary plutons were also responsible for some pronounced ${ }^{18} \mathrm{O}$ and deuterium depletions in the Nelson Batholith. For purposes of discussion, the analyzed samples from the Nelson Batholith are subdivided into five groups (Table 7).

Strong ${ }^{18} \mathrm{O}$ depletions are observed only locally in the Nelson Batholith, principally in the Southern Area, where several Coryell porphyry samples have $\delta^{18} \mathrm{O}=+0.7$ to -5.0 ; this zone of strong ${ }^{18} \mathrm{O}$ depletions also extends outward into the Mesozoic country rocks (Table 7). Some other strongly ${ }^{18} \mathrm{O}$-depleted samples are a basaltic dike (323b) and a pyriterich, hydrothermally altered quartz diorite (324), both of which are from the Slocan Lake Area along the east shore of Slocan Lake, and a chloritized granodiorite from the Northwestern Area, collected next to a prominent epidote-quartz vein at Needles on the west side of Arrow Lake (sample 320). It is interesting that all of these ${ }^{18} \mathrm{O}$-depleted samples from the Nelson Batholith were collected either (1) in close proximity to the Tertiary Coryell porphyry intrusions, or (2) along the edge of one of the large, narrow, north trending lakes that are so prominent in southern British Columbia. Analogous to the situation described above for the more extensive sample set from Okanagan Lake, it is probable that both Slocan Lake and Arrow Lake occupy fracture zones that represented major hydrothermal conduits for heated Tertiary meteoric waters, as well as access routes for the Tertiary Coryell intrusions.

In contrast to the very limited and local ${ }^{18} \mathrm{O}$ depletions, which can only be produced at high water/rock ratios, the 
TABLE 7. Oxygen and Hydrogen Isotope Analyses of Minerals and Rocks From the Nelson Batholith

\begin{tabular}{|c|c|c|c|c|c|}
\hline Sample & $\begin{array}{l}\text { Rock Type and } \\
\text { Mineralogy }\end{array}$ & $\delta D$ & $\begin{array}{c}\delta^{18} \mathrm{O} \\
\text { Whole Rock }\end{array}$ & $\begin{array}{l}\delta^{18} \mathrm{O} \\
\text { Quartz }\end{array}$ & $\begin{array}{c}\delta^{18} \mathrm{O} \\
\text { Feldspar }\end{array}$ \\
\hline \multicolumn{6}{|c|}{ Northwestern Area } \\
\hline 315 & GD- $f, q, k, b, h, c$ & $-99 b+h+c$ & & 11.2 & 9.1 \\
\hline 317 & GD- $f, q, k, h, c$ & $-147 c+h$ & & 10.1 & 4.3 \\
\hline 319 & $\mathrm{GD}-f, q, k, c$ & $-141 c$ & & 9.5 & 7.6 \\
\hline 320 & $\mathrm{GD}-f, q, k, h, c, e$ & $-163 c+h[-156 e]$ & & 10.2 & $-3.5^{*}$ \\
\hline \multicolumn{6}{|c|}{ Slocan Lake Area } \\
\hline 323 & QD-f, $q, b, h, c$ & $-153 b+h+c$ & & 9.6 & 8.5 \\
\hline $323 a$ & $\mathrm{~A}(\mathrm{D})-f, k, q$ & & 9.2 & & \\
\hline $323 b$ & $\mathbf{B A}(\mathbf{D})-f, c, a$ & & -5.3 & & \\
\hline 324 & QD-f, $q, c$, pyrite & $-150 c$ & & & -5.0 \\
\hline 325 & QD $-f, a, b, c$ & $-151 b+c$ & & 11.4 & 9.6 \\
\hline 326 & MIG- $q, f, b, c$ & $-151 b+c$ & & & 9.8 \\
\hline \multicolumn{6}{|c|}{ Southern Area } \\
\hline 329 & MIG- $f, q, b, c, h$ & $-147 b+c+h$ & & & 7.1 \\
\hline 330 & $\mathrm{DI}-f, q, \bar{h}, b, c$ & $-162 h+b$ & -1.1 & & \\
\hline $331 \mathrm{~A}$ & $\mathrm{PO}-f, k, q, c$ & & -2.2 & $5.8 \mathrm{HF}$ & -4.4 \\
\hline 331B & $\mathrm{PO}-f, k, q, c$ & & +0.7 & $6.1 \mathrm{HF}$ & -3.1 \\
\hline 332 & PO-f, $k, q, c$ & & -5.0 & & \\
\hline 333 & QD $-f, q, b$ & $-138 b$ & & 10.3 & 8.6 \\
\hline \multicolumn{6}{|c|}{ Nelson Area } \\
\hline 335 & QD- $f, q, b, c$ & $-154 b$ & & & 8.6 \\
\hline 336 & QD- $f, q, b, c$ & $-110 b+c$ & & 13.3 & 11.6 \\
\hline 337 & QD-f, $q, b, h, c$ & $-155 b$ & & 12.0 & 9.7 \\
\hline \multicolumn{6}{|c|}{ Craton Section } \\
\hline 338 & QD- $f, q, b, c$ & $-94 b$ & & 11.0 & 9.6 \\
\hline 339 & GD- $f, k, q, b, c$ & $-100 b+c$ & & 10.9 & $8.8 k$ \\
\hline
\end{tabular}

hydrogen isotope data (Table 7, Figure 6) show clearly that meteoric-hydrothermal fluids in fact pervasively altered almost the entire Nelson Batholith. Only four of the analyzed samples have $\delta \mathrm{D}>-138$, namely, the northwesternmost sample analyzed (315) and three samples from the extreme southeastern part of the batholith. Even these four samples, however, have $\delta \mathrm{D}=-94$ to -110 , values below those characteristic of primary magmatic values, and low enough to indicate at least some meteoric-hydrothermal effects. On a $\delta \mathrm{D}-\delta^{18} \mathrm{O}$ feldspar diagram (Figure 6), the Nelson Batholith samples exhibit the familiar "inverted- $L$ "-shaped pattern characteristic of meteoric-hydrothermal alteration [Taylor, $1977]$.

An interesting aspect to the hydrothermal alteration observed in the Nelson Batholith is the large number of low $\delta \mathrm{D}$ values observed in samples that are relatively unchloritized and that contain fresh biotite and hornblende (Table 7, Figure 6). Elsewhere in southern British Columbia, such low $\delta \mathrm{D}$ values are characteristically associated with much heavier chloritization (e.g., Okanagan Lake). This implies that much of this hydrothermal alteration probably occurred at relatively high temperatures $\left(>400^{\circ} \mathrm{C}\right)$, perhaps indicating either proximity to buried Tertiary plutons or that major uplift and erosion has occurred here subsequent to the hydrothermal activity (see the extended discussion of Criss et al. [1982], who describe an analogous situation in the nearby Idaho batholith).

\section{Primary Magmatic ${ }^{18} \mathrm{O} /{ }^{16} \mathrm{O}$ Ratios}

The values of $\delta^{18} \mathrm{O}$ quartz in the granitic plutons vary considerably throughout the Nelson Batholith, attaining the highest value observed anywhere in southern British Columbia, +13.3 . The two principal sets of $\delta^{18} \mathrm{O}$ quartz values in the batholith are indicated by the two stippled patterns shown on
Figure 6; the bulk of the Nelson Batholith has $\delta^{18} \mathrm{O}$ quartz $=$ +9.5 to + 11.0 (labeled West + Craton), but three samples collected near the town of Nelson have $\delta^{18} \mathrm{O}$ quartz $=+11.4$ to +13.3 (labeled East). These data suggest that as we have seen throughout southern British Columbia, the primary $\delta^{18} \mathrm{O}$ values of the granitic magmas continued to increase eastward, finally culminating at a maximum whole-rock $\delta^{18} \mathrm{O}$ value of +11 to +12 in the area between Slocan Lake and Nelson. Farther eastward, across the Kootenay Terrane (Figure 2) and across Kootenay Lake, where the Nelson Batholith impinges upon the North American craton, the whole-rock $\delta^{18} \mathrm{O}$ values of the granitic rocks go back down to lower $\delta^{18} \mathrm{O}$ values $(+9.5$ to +10.0$)$. This is the same type of phenomenon seen farther south in the late Mesozoic batholiths of California and the southwestern United States, where whole-rock $\delta^{18} \mathrm{O}$ reaches values as high as +11 to +12 in the eastern half of the Peninsular Ranges batholith and in central Nevada [Taylor and Silver, 1978; Solomon and Taylor, 1981] before starting back down to lower values as one moves eastward into the craton in Arizona and Utah.

\section{SUMmary OF Hydrothermal EFFECTS IN SOUTHERN British COLUMBIA}

\section{$D / H$ Variations}

The $\mathrm{D} / \mathrm{H}$ variations described above for each of the individual batholithic terranes in southern British Columbia display some interesting regional systematics; these west-to-east $\mathrm{D} / \mathrm{H}$ variations are best shown by projecting the data on a latitudinal cross section (Figure 7). Although the freshest, least altered samples in each terrane typically have $\delta \mathrm{D}$ values close to or within the presently accepted "primary magmatic" $\delta \mathrm{D}$ range of -65 to -85 , the subset of heavily altered granitic rocks exhibits steadily decreasing $\delta \mathrm{D}$ values from west to east. If we 


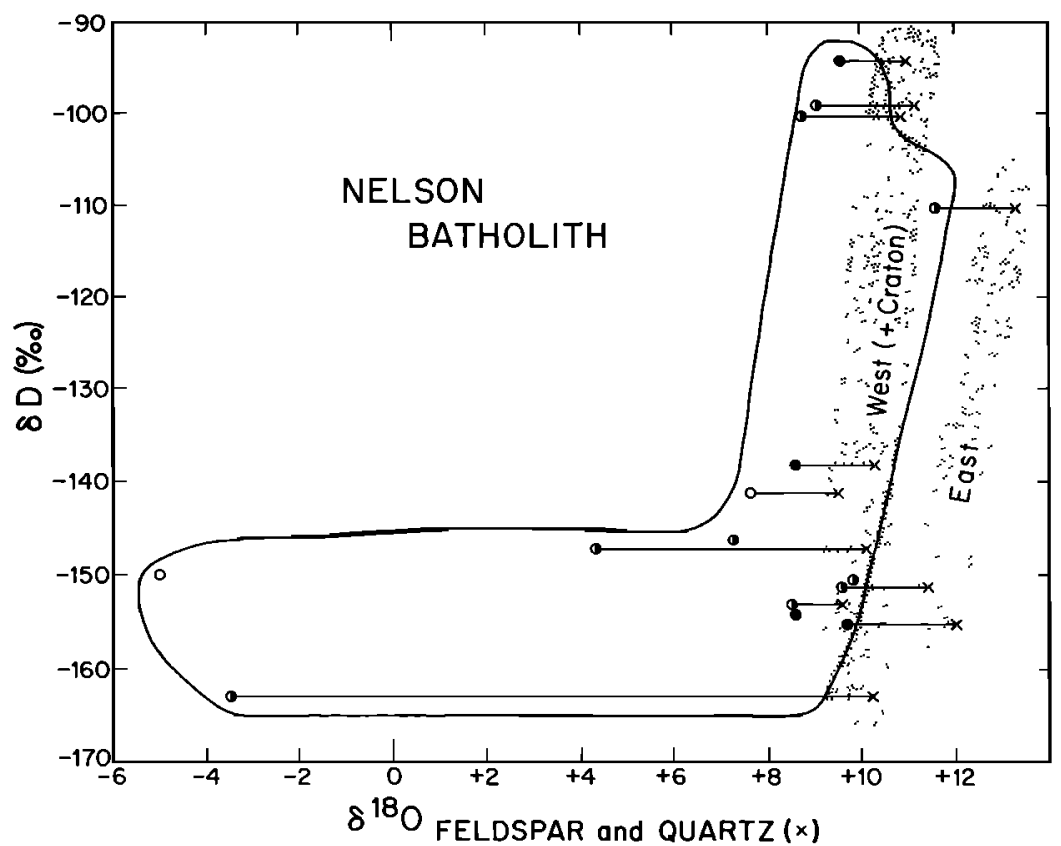

Fig. 6. Plot of $\delta \mathrm{D}$ versus $\delta^{18} \mathrm{O}$ feldspar and quartz for samples of the Nelson Batholith. Symbols are the same as on Figures 3. 4, and 5.

confine the discussion just to samples that show hydrothermal ${ }^{18} \mathrm{O} /{ }^{16} \mathrm{O}$ effects (i.e., those that must have experienced very high water/rock ratios), the measured $\delta \mathrm{D}$ values change systematically as follows:

\begin{tabular}{|c|c|}
\hline Area & $\delta D$ Range, \%o \\
\hline Vancouver Island (except Kennedy Lake) & -46 to -63 \\
\hline Kennedy Lake area & -80 to -94 \\
\hline Western Coast Batholith & -65 to -95 \\
\hline Central Coast Batholith & -80 to -90 \\
\hline Eastern Coast Batholıth & -114 to -130 \\
\hline Princeton area & -107 to -129 \\
\hline Raft Batholith & -125 to -136 \\
\hline Okanagan Batholith & -130 to -151 \\
\hline Nelson Batholith & -147 to -163 \\
\hline
\end{tabular}

The west-to-east $\delta \mathrm{D}$ changes in the above table are similar to what is observed in present-day meteoric waters in British Columbia (Figure 8). Neither of the two older batholiths that have preserved early Mesozoic K/Ar ages (namely the Guichon and Thuya batholiths) are listed in the above table because neither shows any evidence of interaction with such low- $\delta \mathrm{D}$ meteoric waters. All of the Guichon and Thuya samples have essentially "normal" $\delta \mathrm{D}$ and $\delta^{18} \mathrm{O}$ values, as is shown in Figure 7. The most plausible explanation for this phenomenon is that the same process that helped preserve the "old" $\mathrm{K} / \mathrm{Ar}$ ages also is responsible for the absence of late Mesozoic and Cenozoic meteoric-hydrothermal activity. The only such process that seems feasible is the isolation of these two batholiths from later intrusive activity. That is exactly what seems to have occurred because both of these batholiths are relatively small and they crop out at considerable distance from any of the other batholiths of southern British Columbia (Figure 2). Also, whereas most of the latter are composite batholiths containing plutons with ages ranging from early Mesozoic to mid-Tertiary, the Guichon and Thuya batholiths exclusively exhibit only early Mesozoic ages.

Because most batholiths show at least some evidence for interactions with surface-derived waters, we conclude that either (1) the epizonal portions of these Late Triassic or Early
Jurassic batholiths have been eroded away, or (2) during the early Mesozoic the surface waters in this area were richer in deuterium, either because the terrane was located at a lower latitude where the climate was much warmer or because at the time of emplacement that terrane lay directly adjacent to or within an oceanic environment.

Process 2 above is the most likely because of the relatively abundant chlorite and slight deuterium depletions observed in the Thuya Batholith (Table 5) and because we know that part of the Guichon Batholith is made up of the Bethlehem (Highland Valley) porphyry copper deposit; such ore deposits are typically epizonal, and their hydrothermal systems typically involve surface waters [Sheppard et al., 1971; Taylor, 1974b]. Also, as many workers have demonstrated (e.g., Criss et al. [1982] for the Idaho batholith), if major uplift and erosion occurs, the original $\mathrm{K} / \mathrm{Ar}$ ages will be reset as the terrane passes upward through the "blocking temperature" for Ar diffusion in biotite. Thus the stable isotope data and the evidence for preservation of primary K/Ar ages provide support for the idea [Symons, 1983a; Symons and Litalien, 1984] that the Guichon-Thuya area (part of the Quesnel Terrane, see Monger and Berg [1984]) originated farther south and/or in a more coastal or maritime environment, where the $\delta \mathrm{D}$ values of the surface meteoric waters were much higher than they are at present in the inland portion of southern British Columbia (Figure 8).

An interesting feature of Figure 7 is that the most profound change in the $\mathrm{D} / \mathrm{H}$ ratio of these granitic batholiths takes place approximately along the central axis of the Coast Plutonic Complex. This implies that during the later stages of formation of the Okanagan, Raft, and Nelson batholiths ( $\sim 40$ Ma), the surface area directly west of these batholiths must have been a pronounced topographic high. This is reasonable in terms of continuing isostatic readjustments and also because of the likelihood that dacitic and andesitic volcanoes were probably abundant in that area. Such a topographic barrier would cause a dramatic west-to-east shift in the isotopic compositions of meteoric waters, as is the case at present (see Figure 8). 


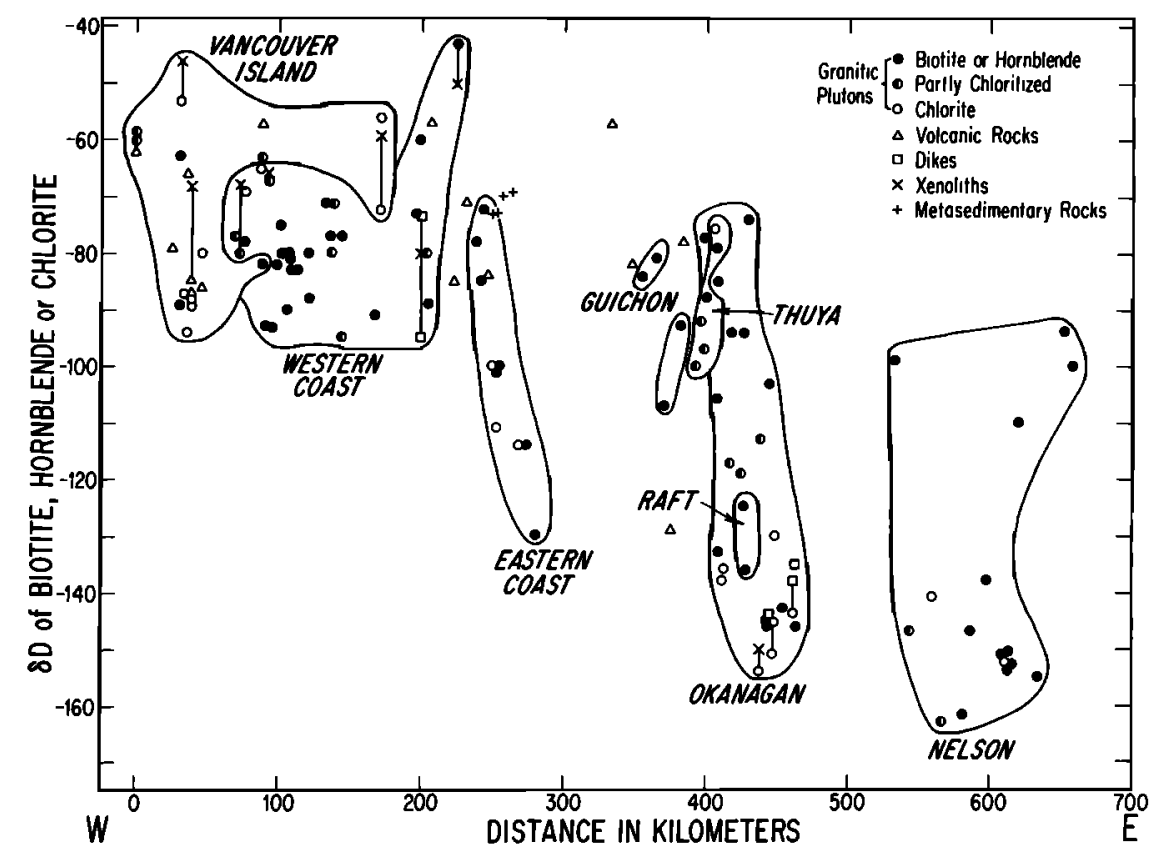

Fig. 7. Plot of $\delta \mathrm{D}$ of all samples studied in this work versus distance eastward from the Pacific Coast of Vancouver Island.

\section{Combined $\mathrm{D} / \mathrm{H}-{ }^{18} \mathrm{O} /{ }^{16} \mathrm{O}$ Effects}

If we examine the geographic variations of both $\delta \mathrm{D}$ and $\delta^{18} \mathrm{O}$ throughout southern British Columbia, we obtain a series of L-shaped patterns, each one characteristic of a specific geographic area. These effects show up when $\delta \mathrm{D}$ is plotted against either $\delta^{18} \mathrm{O}$ feldspar or against $\Delta^{18} \mathrm{O}$ quartz-feldspar (Figures 9 and 10). On both diagrams, the horizontal arms of each " $L$ " represent the samples that have been subjected to the highest water/rock ratios; in each case, the horizontal arm displays an approximately constant $\delta \mathrm{D}$ value characteristic of that particular geographic area.

Making certain assumptions about the temperature and other parameters [see Taylor, 1977], we may calculate the $\delta \mathrm{D}$ value of the $\mathrm{H}_{2} \mathrm{O}$ that coexisted with the hydrothermal chlorites and biotites in the heavily altered samples, as shown on Figure 11. Such a $\delta \mathrm{D}$ value will represent the original $\delta \mathrm{D}$ value of the surface waters involved in the hydrothermal convective systems at the time of alteration, so by plotting this value on the meteoric water line [Craig, 1963], we can obtain a complete picture of the original isotopic compositions of these waters prior to their entrance into each hydrothermal system; such a calculation was carried out for the various geographic areas delineated on Figure 9, with the results as shown in Figure 11.

Figure 11 shows that in direction, but not in magnitude, the same general west-to-east pattern of $\mathrm{D} / \mathrm{H}$ and ${ }^{18} \mathrm{O} /{ }^{16} \mathrm{O}$ that exists in the meteoric waters of southern British Columbia today (Figure 8) also must have existed when the bulk of the hydrothermal alteration occurred in the late Mesozoic and Cenozoic. In all these localities, the calculated $\delta \mathrm{D}$ values of the hydrothermal fluids are higher than those of present-day local groundwaters. These isotopic data are thus nicely compatible with the types of northward translations of the batholithic terranes suggested by various workers [e.g., Beck et al., 1981; Monger and Irving, 1980; Symons and Litalien, 1984]. However, they are also compatible simply with an overall shift from a much warmer and less continental climate everywhere in southern British Columbia during the late Mesozoic and early Cenozoic.

\section{$\Delta^{18} O$ Values of Coexisting Quartz and Feldspar}

Figure 10 summarizes the $\delta \mathrm{D}$ values and $\delta^{18} \mathrm{O}$ data $\left(\delta^{18} \mathrm{O}\right.$ quartz minus $\delta^{18} \mathrm{O}$ feldspar) on mineral pairs in the granitic rocks of southern British Columbia. Only a few rocks (principally in the Central Coast Batholith) display both primary, magmatic $\delta \mathrm{D}$ values and "normal" $\Delta^{18} \mathrm{O}$ quartz-feldspar values. Thus virtually all the granitic rocks in southern British Columbia exhibit some evidence for subsolidus hydrothermal exchange.

Nonetheless, except for isolated samples, only in a few selected areas were very large water/rock ratios involved, as evidenced by anomalous $\Delta^{18} \mathrm{O}$ quartz-feldspar values (either $>2.5$ or $<0.5$ ); these areas are (1) Kennedy Lake area on Vancouver Island, (2) Powell River traverse in the Western Coast Batholith, (3) Okanagan Lake traverse in the Okanagan Batholith, and (4) within the Nelson Batholith at localities near the mid-Tertiary Coryell intrusions or along linear topographic depressions (Slocan Lake, Arrow Lake). Except on Vancouver Island, these areas of high fluid/rock ratio all involved low- ${ }^{18} \mathrm{O}$, meteoric groundwaters. On Vancouver Island, the fluids were much higher in ${ }^{18} O\left(\delta^{18} O \geq 0\right)$ and were probably ocean waters or marine formation waters.

The ${ }^{18} \mathrm{O} /{ }^{16} \mathrm{O}$ Exchange Behavior of Coexisting Quartz and Feldspar

In a previous paper [Magaritz and Taylor, 1976a], we reported on ${ }^{18} \mathrm{O} /{ }^{16} \mathrm{O}$ zoning in quartz grains from a hydrothermally altered granite. A similar study was made in the present work on individual quartz crystals carefully separated from a granodiorite in the Okanagan Batholith (Figure 12). Four separate fluorine-stripping experiments on these quartz grains give similar results and indicate that the cores of the grains ( $75 \%$ of the total volume) have a uniform $\delta^{18} \mathrm{O} \approx$ +10.0 , higher than the average $\delta^{18} \mathrm{O}$ quartz value of +7.1 , and much higher than the first $2-8 \%$ of the oxygen removed from the quartz crystals $\left(\delta^{18} \mathrm{O}=-6.8\right.$ to -1.1 , Figure 12). These results are best interpreted as indicating that the quartz grains contain primary, unexchanged cores having the original magmatic $\delta^{18} \mathrm{O}$ values appropriate for this granodiorite. Sub- 


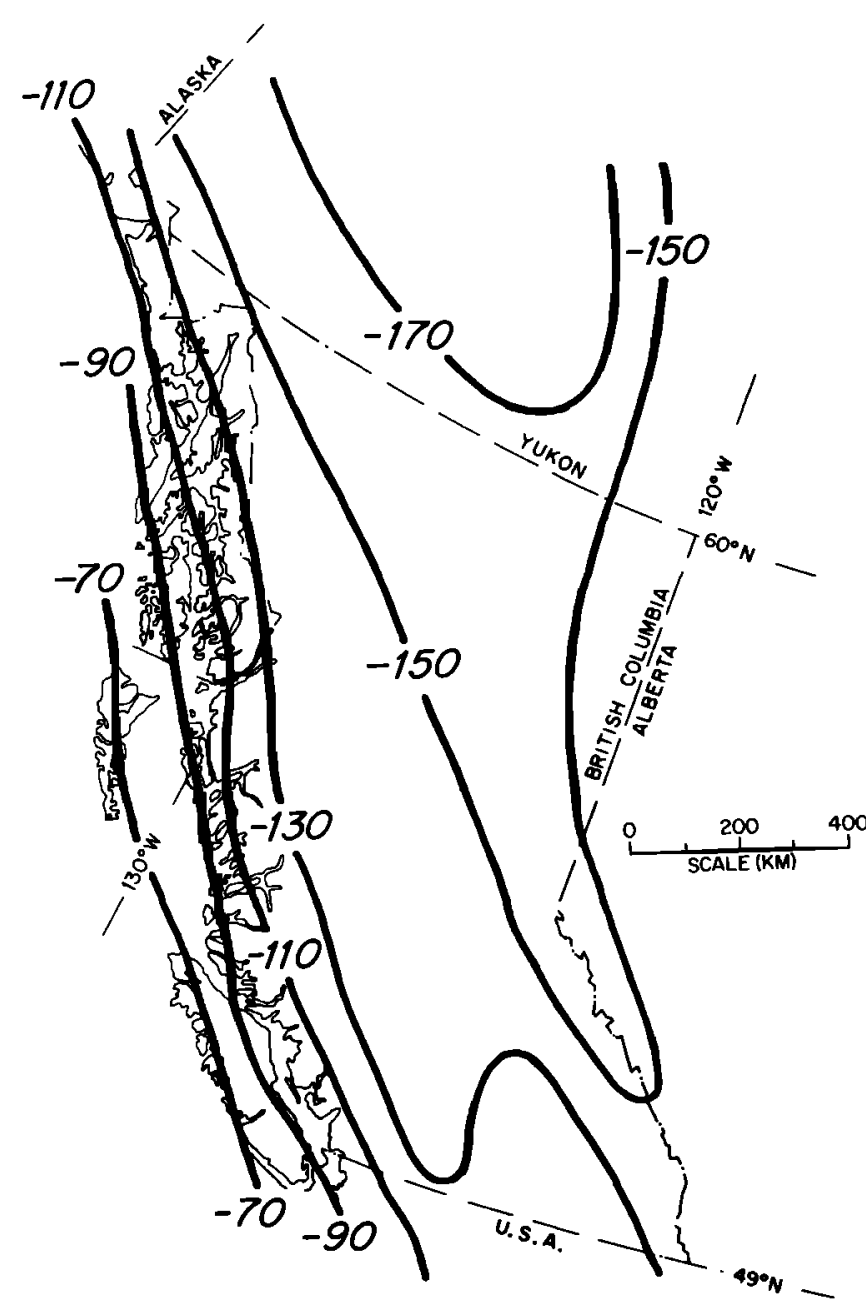

Fig. 8. Map of British Columbia showing in a generalized fashion the range of $\delta \mathrm{D}$ values in present-day meteoric waters (lakes, streams, rivers, groundwaters, etc.) in this region (after data by Friedman et al. [1964], Yapp and Epstein [1982], Hitchon and Krouse [1972], and Clark et al. [1982]).

sequently, during the Tertiary hydrothermal episode, the outermost, more exposed portions of the quartz grains were strongly depleted in ${ }^{18} \mathrm{O}$ by exchange with the meteorichydrothermal fluids. This event lowered the mean $\delta^{18} \mathrm{O}$ of the coexisting feldspar from about +8.5 all the way down to a value of -2.8 , but lowered the mean $\delta^{18} \mathrm{O}$ of the quartz only about 3\%, down to +7.1 (Table 6). Overall, the feldspar underwent much greater ${ }^{18} \mathrm{O}$ depletion than the quartz, but as the data in Figure 12 show, part of the quartz was lowered to an even greater degree than was the bulk of the feldspar. This probably implies that the feldspar in this rock is isotopically zoned as well, apparently locally having $\delta^{18} \mathrm{O}$ as low as -10 ; however, we have not undertaken any $F_{2}$-stripping experiments on the feldspars to demonstrate these effects directly.

We have examined the $F_{2}$-stripped quartz grains under high magnification, using before-and-after SEM photographs (available from the authors on request). As might be a priori expected, these SEM photographs show that the fluorine attacks the quartz grains in an irregular fashion, preferentially liberating oxygen along cracks and imperfections, as well as also leaving a reacted surface with a very irregular, "pitted" appearance on a micron scale. Apparently, the fluorine is following essentially the same access routes followed by the hydrothermal fluids millions of years earlier, reacting with those parts of the quartz grains that were least protected from ${ }^{18} \mathrm{O} /{ }^{16} \mathrm{O}$ exchange with the hydrothermal fluids (i.e., the $\mathrm{SiO}_{2}$ closest to grain boundaries and microcracks). $O$ 'Neil and Taylor [1967] observed a somewhat analogous phenomenon is laboratory experiments on feldspars, where it was shown that feldspars that had undergone a previous hydrothermal ${ }^{18} \mathrm{O} /{ }^{16} \mathrm{O}$ exchange event reacted much faster with hydrothermal fluids than pristine, unexchanged feldspars.

Most of the samples we have analyzed in Tables 2-7 would not show such extreme zoning as that displayed in Figure 12. However, measurable ${ }^{18} \mathrm{O} /{ }^{16} \mathrm{O}$ zoning is probably present in all quartz samples in which the $\delta^{18} \mathrm{O}$ of the coexisting feldspar has been changed by more than $2 \%$ and the ${ }^{18} \mathrm{O}$ depletions are likely to be greatest in those quartz samples that are the finest-grained and/or which have the lowest modal abundance. As shown on Figure 13, all of the samples from a given geographic region that display a marked ${ }^{18} \mathrm{O}$ depletion of the feldspar also show a distinctive, but much smaller, ${ }^{18} \mathrm{O}$ depletion in the coexisting quartz (typically only about $20 \%$ as much as in the feldspar). These types of steeply sloping isotopic patterns involving quartz and feldspar in granitic rocks, or pyroxene and feldspar in gabbroic rocks, have now been recognized in many areas of intense hydrothermal alteration (e.g., see Taylor and Forester [1979], Criss and Taylor [1983], and Taylor [1983]).

\section{Summary of Primary ${ }^{18} \mathrm{O} /{ }^{16} \mathrm{O}$ Ratios of Granitic Plutons}

Fairly regular west-to-east changes are shown by the steeply dipping data point envelopes for each geographic area delineated on Figure 13. The patterns are regular enough that the original $\delta^{18} \mathrm{O}$ quartz and $\delta^{18} \mathrm{O}$ feldspar in each granitic pluton can be estimated by simple extrapolation upward (or downward in the case of the Vancouver Island data) along the steep trajectories to $\Delta^{18} \mathrm{O}$ values of $1.0-2.5$ (i.e., between the two $45^{\circ}$ lines on the diagram). From these extrapolated values, one can accurately calculate whole-rock $\delta^{18} \mathrm{O}$ values from modal data (Table 8). Figure 13 and Table 8 summarize in a succinct fashion the west-to-east variation in the primary ${ }^{18} \mathrm{O} /{ }^{16} \mathrm{O}$ ratios of the granitic rocks of southern British Columbia, as well as showing that hydrothermal alteration at very high fluid/rock ratios has occurred locally in every one of the areas studied, with the possible exception of the early Mesozoic Thuya Batholith. The lowest "primary" $\delta^{18} \mathrm{O}$ values $(+3$ to +5$)$ are found locally in the Western Coast Batholith, but as discussed above, these samples may represent low- ${ }^{18} \mathrm{O}$ magmas that obtained their $\delta^{18} \mathrm{O}$ values at a high level in the crust (e.g., see Taylor [1977] and Forester and Taylor [1977]). Most of the other $\delta^{18} \mathrm{O}$ values listed in Table 8 probably represent truly primary magmatic values indicative of ${ }^{18} \mathrm{O} /{ }^{16} \mathrm{O}$ variations in the source (melting) regions of these granitic magmas. These $\delta^{18} \mathrm{O}$ values are similar to those given above in the detailed discussions of each area in British Columbia, but they differ slightly because by means of the extrapolations on Figure 13, we are now correcting for the hydrothermal ${ }^{18} \mathrm{O} /{ }^{16} \mathrm{O}$ exchange effects in the quartz in a more systematic and quantitative fashion. Note that the primary $\delta^{18} \mathrm{O}$ values of the Tertiary Coryell porphyries are very poorly constrained because of the lengths of the extrapolations for such strongly ${ }^{18} \mathrm{O}$-depleted samples.

Comparing the data in Table 8 with previous ${ }^{18} \mathrm{O} /{ }^{16} \mathrm{O}$ studies of Cordilleran batholiths farther south [e.g., Taylor and Silver, 1978; Silver et al., 1979], we observe that the granitic plutons of the Western and Central Coast Batholith and Vancouver Island are isotopically similar to the plutons in the 


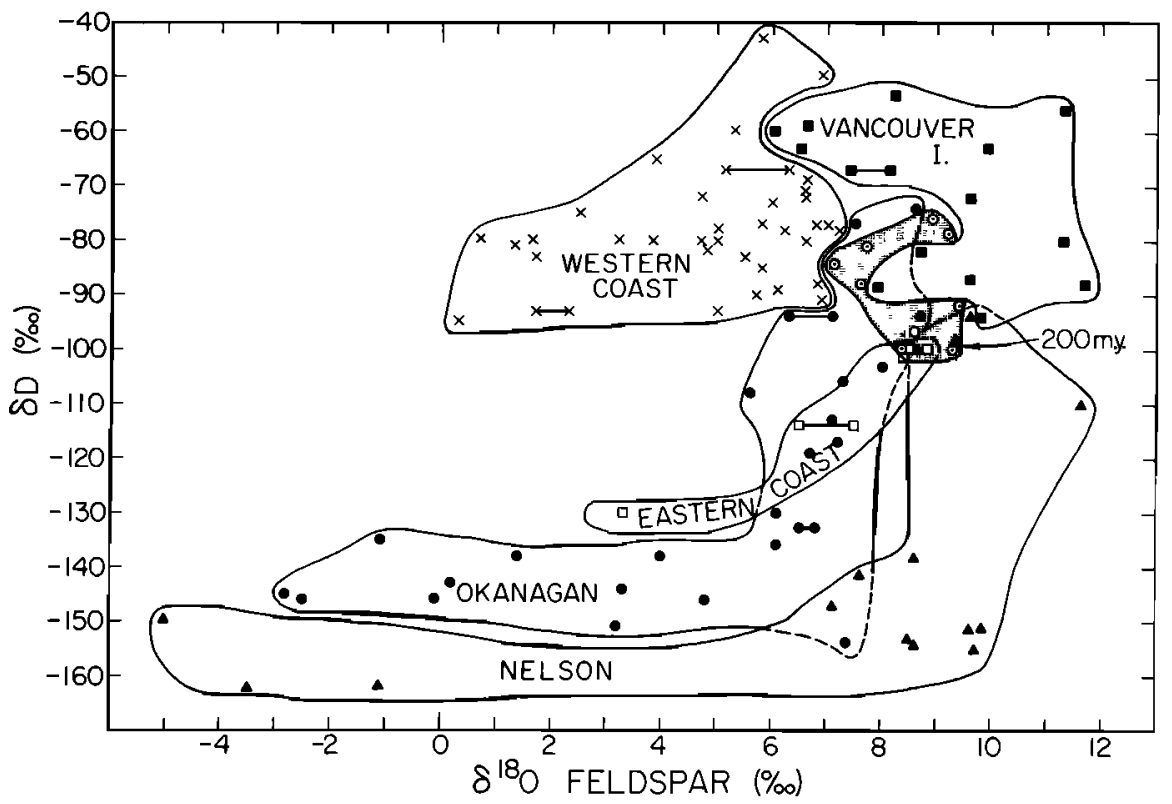

Fig. 9. Plot of $\delta \mathrm{D}$ versus $\delta^{18} \mathrm{O}$ feldspar for samples of the various granitic batholiths studied in this research. The stippled area labeled 200 m.y. indicates samples from the relatively old Thuya and Guichon batholiths (see text).

western half of the Peninsular Ranges Batholith (PRB) of southern and Baja California. The latter have the isotopic characteristics of a primitive, oceanic island arc type assemblage in which there has been some mixing with a high- $\delta^{18} \mathrm{O}$ continentally derived component that becomes progressively more important to the east (sedimentary rocks?). A component of ${ }^{18} \mathrm{O}$-enriched eugeosynclinal material (graywackes or altered mafic volcanics) also cannot be ruled out in these kinds of rocks, especially for the magmas that formed the Wrangellia Terrane (Vancouver Island) intrusions. It is in- teresting that many of the same kinds of isotopic features seen in the rocks of Vancouver Island (e.g., reversed quartz-feldspar $\Delta^{18} \mathrm{O}$ values) are also observed along the extreme western (epizonal) edge of the PRB in Baja California, where intrusion occurred in a submarine environment, and convectively circulating seawater-derived pore fluids were shown to have played a major role [Taylor and Silver, 1978].

The Central Coast Batholith of southern British Columbia has such low $\delta^{18} \mathrm{O}$ values $(+5.5$ to +7.0$)$ that it must be dominantly derived from the upper mantle end-member with

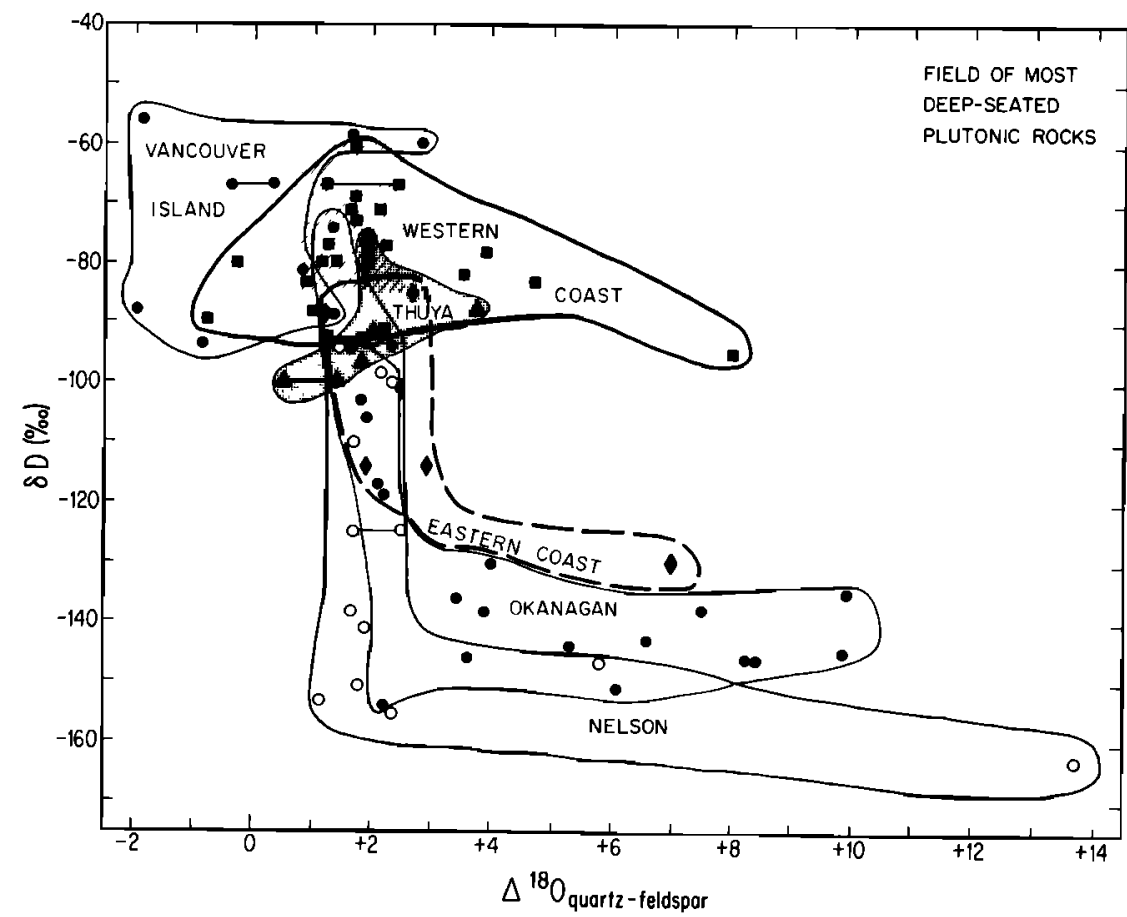

Fig. 10. Plot of $\delta \mathrm{D}$ versus $\Delta^{18} \mathrm{O}$ quartz-feldspar $\left(\delta^{18} \mathrm{O}\right.$ quartz minus $\delta^{18} \mathrm{O}$ feldspar) for coexisting minerals from the same granitic rock sample. Note that only a few samples of the granitic plutons of southern British Columbia (mainly from the Coast and Thuya batholiths) have both normal, magmatic $\delta \mathrm{D}$ values and normal, magmatic $\Delta^{18} \mathrm{O}$ quartz-feldspar values. 


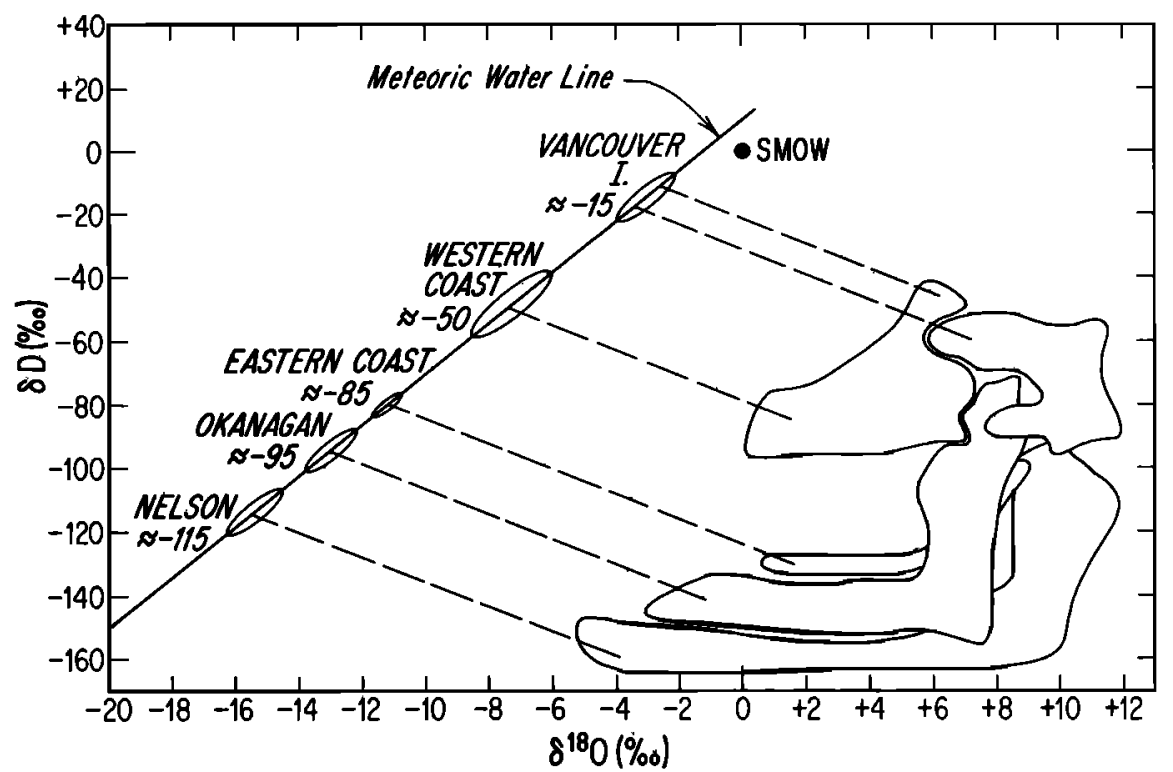

Fig. 11. Plot of $\delta \mathrm{D}$ versus $\delta^{18} \mathrm{O}$ feldspar, showing the various batholith fields from Figure 9 , the meteoric water line of Craig [1963], and the calculated $\delta D$ and $\delta^{18} O$ values of the pristine, unexchanged meteoric waters that were the source of the hydrothermal fluids that produced the various "inverted-L" patterns in each batholith in southern British Columbia (see Taylor [1977] for details of the calculations).

little or no mixing with a higher- ${ }^{18} \mathrm{O}$ continental or sedimentary component. In that respect it appears to be similar to the pristine, low- ${ }^{18} \mathrm{O}$ magmatic end-member that formed much of the western part of the PRB. It will be interesting to obtain some ${ }^{87} \mathrm{Sr} /{ }^{86} \mathrm{Sr}$ initial values on these rocks to check this conclusion.

The $\delta^{18} \mathrm{O}$ values of the other batholiths farther to the east in southern British Columbia (Table 8) require that, as in the PRB, some type of higher- ${ }^{18} \mathrm{O}$ component must be involved in the genesis of these magmas in addition to the component from the upper mantle. This higher- ${ }^{18} \mathrm{O}$ component is most apparent in the extremely high $-{ }^{18} \mathrm{O}$ granitic plutons from the south central portion of the Nelson Batholith, near the town of Nelson (Table 8). Just as is the case farther to the south in Idaho [Criss and Taylor, 1983], in Nevada and southeastern California [Solomon and Taylor, 1981], and in southern and Baja California [Taylor and Silver, 1978], this zone of ${ }^{18} \mathrm{O}$-rich, Mesozoic tonalities and granodiorites closely coincides with a very thick prism of late Precambrian to early Mesozoic geosynclinal sedimentary rocks that border the North American craton all the way from Mexico to Canada. In the Idaho and Nelson Batholith areas, this zone specifically

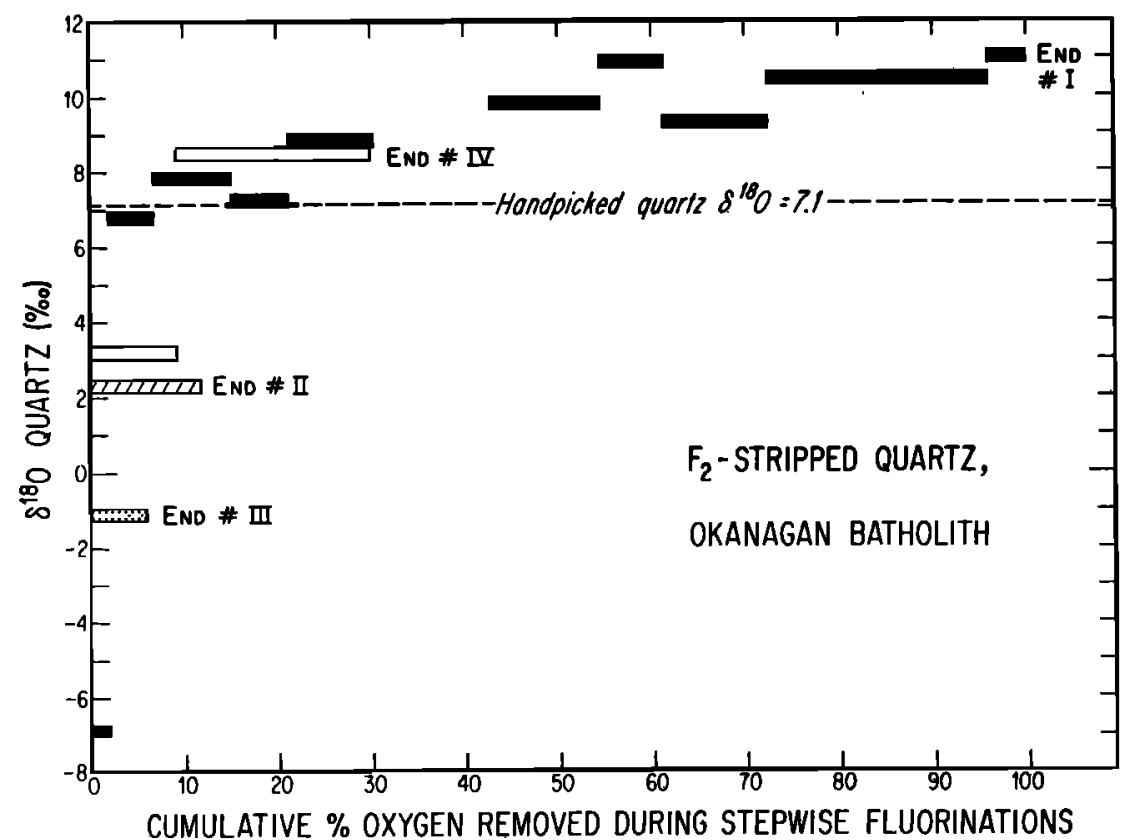

Fig. 12. Plot of $\delta^{18} \mathrm{O}$ quartz versus the cumulative oxygen released during stepwise fluorination of a hand-picked quartz separate from a granodiorite collected in the Okanagan Lake section of the Okanagan Batholith. Four separate stripping experiments were done (I, II, III, and IV), only one of which (I) was carried out to completion. The dashed line indicates the bulk $\delta^{18} \mathrm{O}$ value of the quartz separate, analyzed in the normal way. See Magaritz and Taylor [1976a] for details of the fluorine-stripping procedure. 


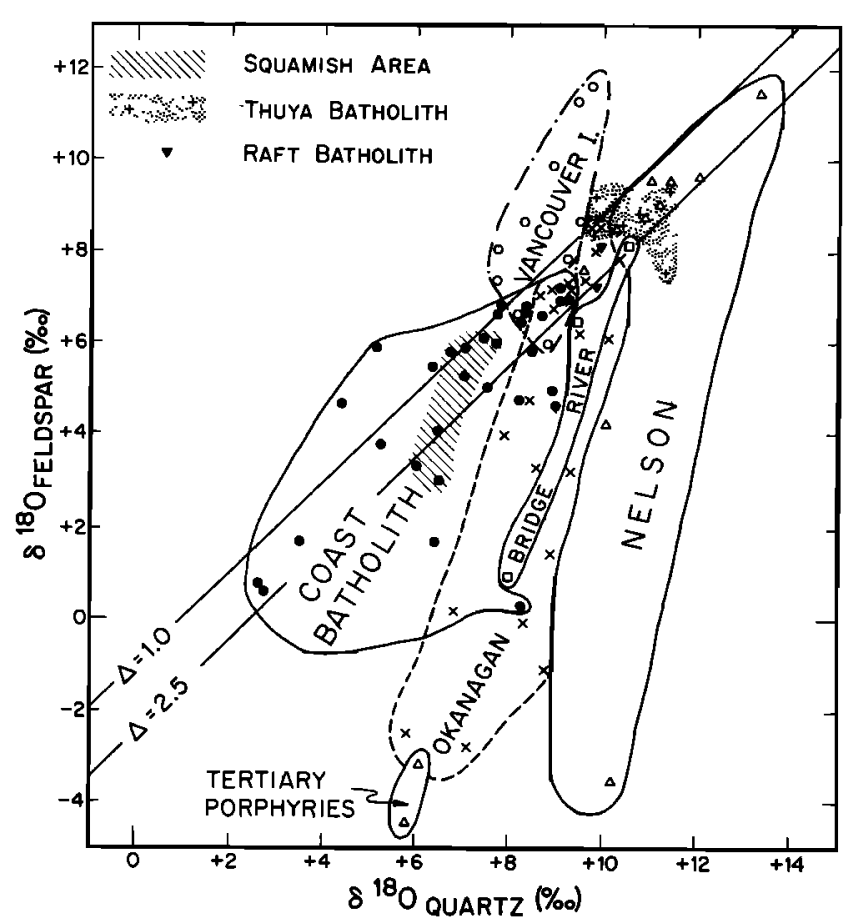

Fig. 13. Plot of $\delta^{18} \mathrm{O}$ feldspar versus $\delta^{18} \mathrm{O}$ of coexisting quartz from various granitic plutons throughout southern British Columbia. The samples labeled Bridge River are from the Eastern Coast Batholith. The Tertiary porphyries are the Coryell intrusions from the Nelson Batholith. Note the steeply sloping data point envelopes that are characteristic of each geographic region and which have now been shown to be general features of hydrothermally altered rocks (see text). The diagonal-lined pattern is a set of samples collected between Squamish and Horseshoe Bay in the Central Coast Batholith; this subset of samples also shows the characteristic steeply sloping pattern. The $45^{\circ}$ diagonal lines at $\Delta=1.0$ and $\Delta=2.5$ represent the range of normal quartz-feldspar ${ }^{18} \mathrm{O} /{ }^{16} \mathrm{O}$ fractionations in plutonic granitic rocks.

includes the Belt Series argillites and sandstones, which are known to be relatively ${ }^{18} \mathrm{O}$-rich $\left(\delta^{18} \mathrm{O}=+13\right.$ to +20 [Eslinger and Savin, 1973]). We conclude that this zone of high $-{ }^{18} \mathrm{O}$ geosynclinal sedimentary rocks was partially melted at depth and provided one of the geochemical components now seen in the Mesozoic plutons of southeastern British Columbia. In spite of the paucity of samples, it is also tempting to speculate that the trend back down to slightly lower $\delta^{18} \mathrm{O}$ values in the extreme eastern part of the Nelson Batholith (Craton Section) is a result of the involvement of

TABLE 8. Range of Primary Whole-Rock $\delta^{18} \mathrm{O}$ Values in the Granitic Plutons of Southern Britısh Columbia, Based on Extrapolations From Figure 13

\begin{tabular}{lr}
\hline \multicolumn{1}{c}{ Area } & $\delta^{18} \mathrm{O}$ Range \\
\hline $\begin{array}{l}\text { Central Coast Batholith } \\
\quad \text { (1ncluding Squamish area) }\end{array}$ & +5.5 to +7.0 \\
Vancouver Island & \\
$\quad$ (and Western Coast Batholith) & +7.0 to +8.5 \\
Eastern Coast, Raft, and & +7.5 to +9.5 \\
$\quad$ Okanagan batholiths (including & \\
$\quad$ Bridge River Terrane) & \\
Thuya Batholith (early Mesozoic) & +9.0 to +10.5 \\
Nelson Batholith (overall) & +9.0 to +12.0 \\
Western portion & +9.0 to +10.5 \\
$\quad$ Nelson area & +10.0 to +12.0 \\
Craton section & +9.0 to +10.0 \\
Tertiary Coryell Porphyries & +7.5 to $+9.5 ?$ \\
$\quad$ (poorly determined) & \\
\hline
\end{tabular}

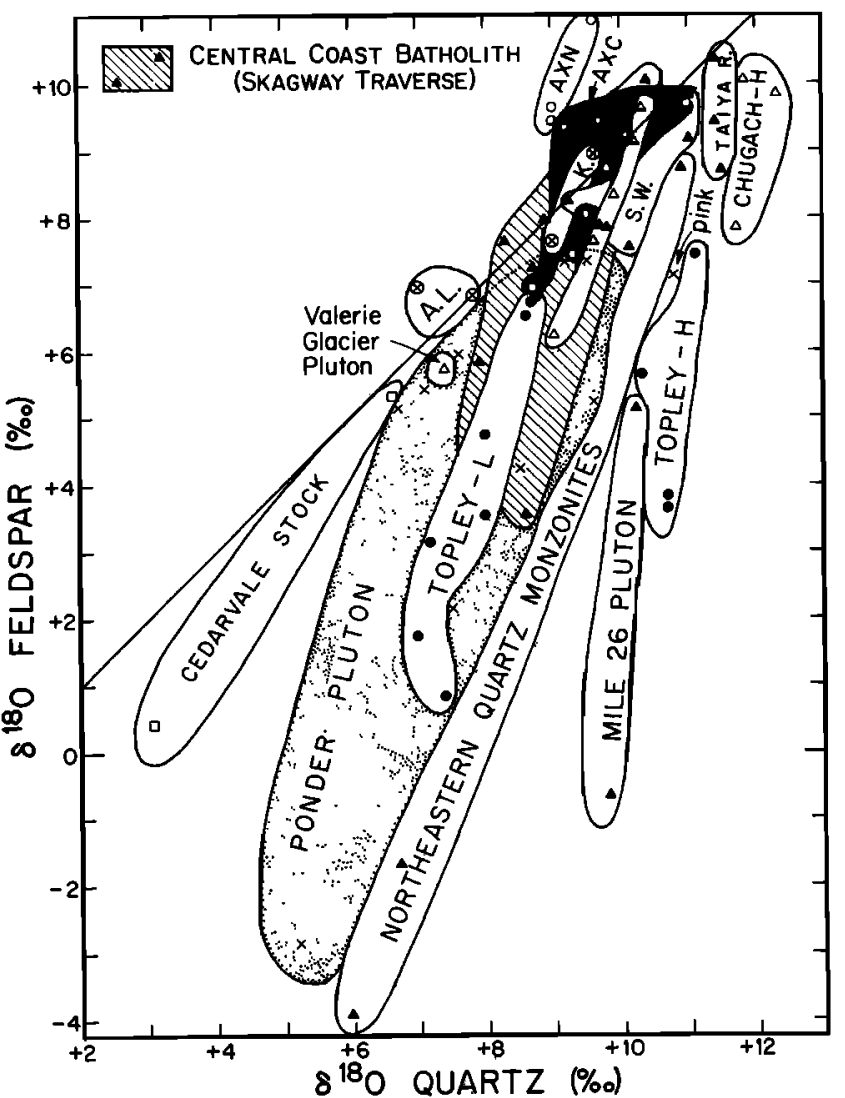

Fig. 14. A diagram of the same type shown in Figure 13, showing analogous $\delta^{18} \mathrm{O}$ quartz and $\delta^{18} \mathrm{O}$ feldspar data collected along traverses farther north in British Columbia and SE Alaska, within the areas delineated on Figure 1. The Cedarvale stock, Ponder pluton, Alastair Lake pluton (A.L.) and the Kasiks pluton (K.) are all from an area near Terrace, just east of Prince Rupert [Magaritz and Taylor, 1976a]. Pink, pink facies of Ponder pluton. Topley-L and Topley-H are two different groups of samples from the Jurassic Topley intrusions much farther east $\left(\mathrm{H}\right.$, high- ${ }^{18} \mathrm{O}$ group; $\mathrm{L}$, low- ${ }^{18} \mathrm{O}$ group). The Taiya River, Mile 26, Northeastern Quartz Monzonites, and S.W. (= southwest) plutons, together with the samples in the diagonal striped region, are part of the Skagway traverse through the Coast Batholith [Magaritz and Taylor, 1976b; Barker et al., 1984]. The AXN and AXC (black field) samples are from two different subterranes of the Alexander Terrane (Annette and Craig, respectively, see Monger and Berg [1984] in southern SE Alaska [Gehrels and Taylor 1984]. The Chugach-H and Valerie Glacier fields, and the other field containing the open triangles all represent samples from the YakutatMount St. Elias area [Magaritz and Taylor, 1976b; Hudson et al., 1977].

lower- ${ }^{18} \mathrm{O}$ cratonal basement material in the melting process, as has been inferred farther south in the Cordillera [Solomon and Taylor, 1981].

\section{Comparison With Earlier Work in British Columbia AND SE ALASKa}

Finally, in Figures 14, 15, and 16, we compare our data in this work with the earlier data obtained farther to the north along strike and within the same sequence of tectonostratigraphic terranes (see Figure 1). Figure 14 shows that in these northern traverses we obtain the same general kinds of steeply sloping $\delta^{18} \mathrm{O}$ envelopes indicated in Figure 13, proving that many of the northern rocks have also been hydrothermally altered at very high water/rock ratios. However, probably because of the greater tectonic complexity to the north, the relatively simple west-to-east asymmetry in the primary magmatic $\delta^{18} \mathrm{O}$ values is not so apparent. In fact, the 


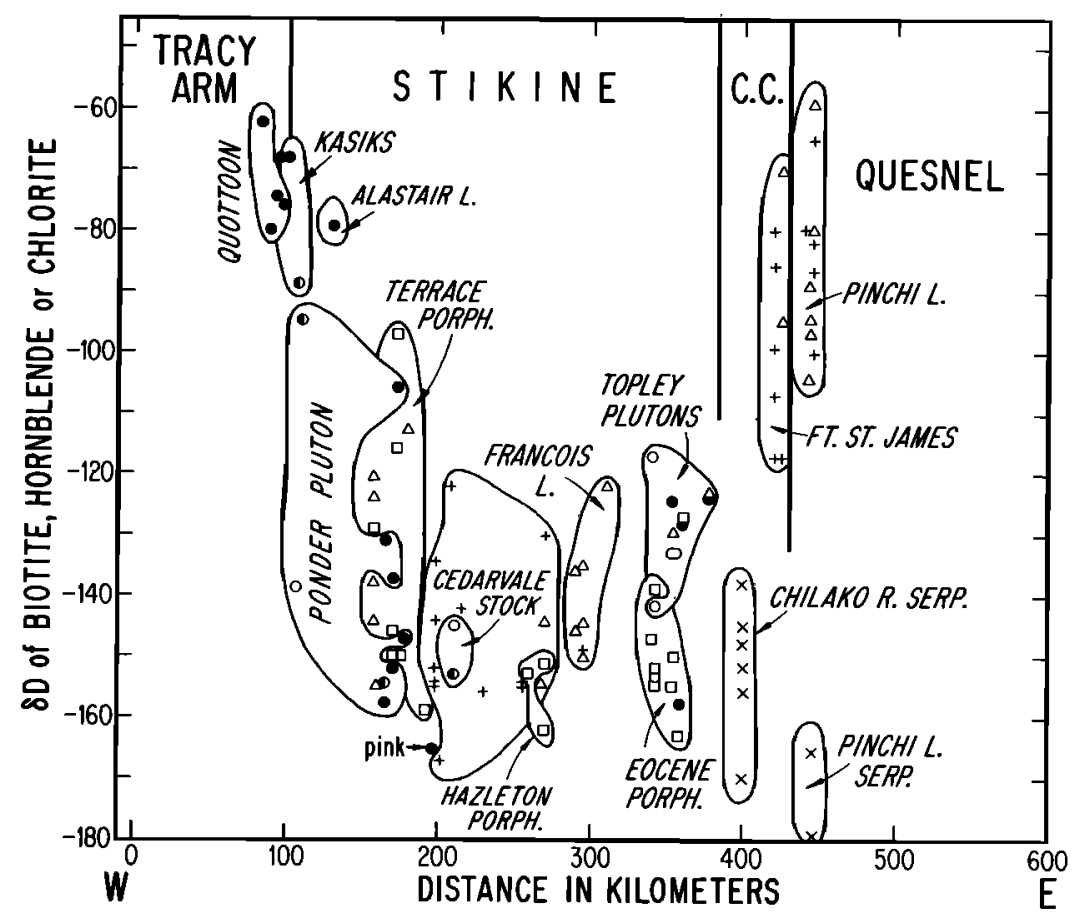

Fig. 15. A diagram of the same type shown in Figure 7, and at the same scale, showing $\delta \mathrm{D}$ data from the Prince Rupert-Prince George Iraverse (areas 4 and 5 on Figure 1) [after Magaritz and Taylor, 1976a]; this includes the region around Francois Lake, Pinchi Lake, Chilako River, and the towns of Terrace, Hazleton, Cedarvale, and Ft. St. James in central British Columbia. PORPH., porphyries; SERP., serpentinites; CC., Cache Creek Terrane; pink, pink facies of Ponder pluton. The different symbols are explained in Figure 7. Distance is measured eastward from the Pacific Coast.

highest- ${ }^{18} \mathrm{O}$ plutons in the northern traverses are located quite far to the west, namely, in the Mount Vancouver and Novatak Glacier plutons from the Chugach Terrane. Of all the samples analyzed farther north, only the Jurassic Topley-H plutons and the Taiya River Flats quartz diorite from the Central Coast Range Batholith near Skagway approach the high $\delta^{18} \mathrm{O}$ values of these Chugach Terrane plutons (Figure 14). However, this lack of high- ${ }^{18} \mathrm{O}$ rocks might be due to the fact that there are no samples in the northern data set from any of the extreme easternmost group of plutons that intrude the Cassiar, Slide Mountain, or Quesnel terranes.

The data obtained on Alexander Terrane plutons from the southern part of Southeastern Alaska by Gehrels and Taylor [1984] make almost a perfect match with the values obtained by us from Vancouver Island in the present work (Figures 13 and 14), and we thus infer a similar origin. In both cases, we see the characteristic reversed $\Delta^{18} \mathrm{O}$ quartz-feldspar values, the evidence for subsolidus enrichment of ${ }^{18} \mathrm{O}$ in the feldspar, and the same general range of calculated primary whole-rock $\delta^{18} \mathrm{O}$ values. However, there does appear to be some geographic asymmetry within the Alexander Terrane; the three westernmost samples studied by Gehrels and Taylor [1984] are from Prince of Wales Island and display the biggest $\Delta^{18} \mathrm{O}$ reversals and the lowest extrapolated whole-rock $\delta^{18} O$ values of any of their samples (AXN field on Figure 14).

There is no evidence in the north for the immense zone of hydrothermal alteration seen along the Powell River traverse on the western edge of the Coast Plutonic Complex. This may be due to the fact that the country rocks are so different because the Coast Batholith in the Prince Rupert area is not intrusive into the eastern edge of the Wrangellia Terrane, as it is to the south. Also, a much greater degree of recent erosion and unroofing has occurred in the Prince Rupert area, exposing much more deeply seated rocks along the western edge of the Coast Batholith [Hollister, 1982; Parrish, 1983].
Except for the Cedarvale stock, which was emplaced just to the east of the Ponder pluton, and which probably obtained its low- ${ }^{18} \mathrm{O}$ characteristics by magmatic interactions with hydrothermally altered country rocks in an epizonal environment (e.g., see Taylor [1977]), the lowest- ${ }^{18} \mathrm{O}$ magmas of the northern traverses are found in the western part of the Coast Plutonic Complex and include the Alastair Lake pluton and some portions of the Ponder pluton. These extrapolated $\delta^{18} \mathrm{O}$ values $(+6$ to +7$)$ are comparable to those in the equivalent (central) part of the Coast Plutonic Complex farther south.

Almost all of the other plutons from the northern traverses that are not specifically singled out above have extrapolated whole-rock $\delta^{18} \mathrm{O}$ values of +7.5 to +10 , within the general range of values observed in most other granitic rocks throughout the world and also similar to the bulk of the $\delta^{18} \mathrm{O}$ values obtained farther south in the Eastern Coast, Raft, Thuya, and Okanagan batholiths and in the western part of the Nelson Batholith. There is no simple geographic pattern apparent in any of the data, however, except that the extrapolated primary $\delta^{18} \mathrm{O}$ values of the northeastern quartz monzonites from the Skagway traverse do tend to be fairly ${ }^{18} \mathrm{O}$-rich (Figure 14). There may, however be an age correlation. Barker et al. [1984] have shown that the plutons in the central part of the Skagway traverse (diagonal striped region on Figure 14) are Eocene in age (48-54 $\mathrm{Ma} \mathrm{U} / \mathrm{Pb}$ ages); these plutons have relatively low primary $\delta^{18} \mathrm{O}$ values compared to the older plutons directly to the $\mathrm{NE}$ and $\mathrm{SW}$, and their $\delta^{18} \mathrm{O}$ values are also very similar to portions of the Eocene Ponder pluton much farther to the south.

Thus, although most of the northern magmas do require a significant amount of a high- ${ }^{18} \mathrm{O}$ component derived from the continental crust or from sedimentary rocks, it is not apparent that this component became increasingly more important from west to east, in the simple fashion that it did farther south in British Columbia and in the western United States 


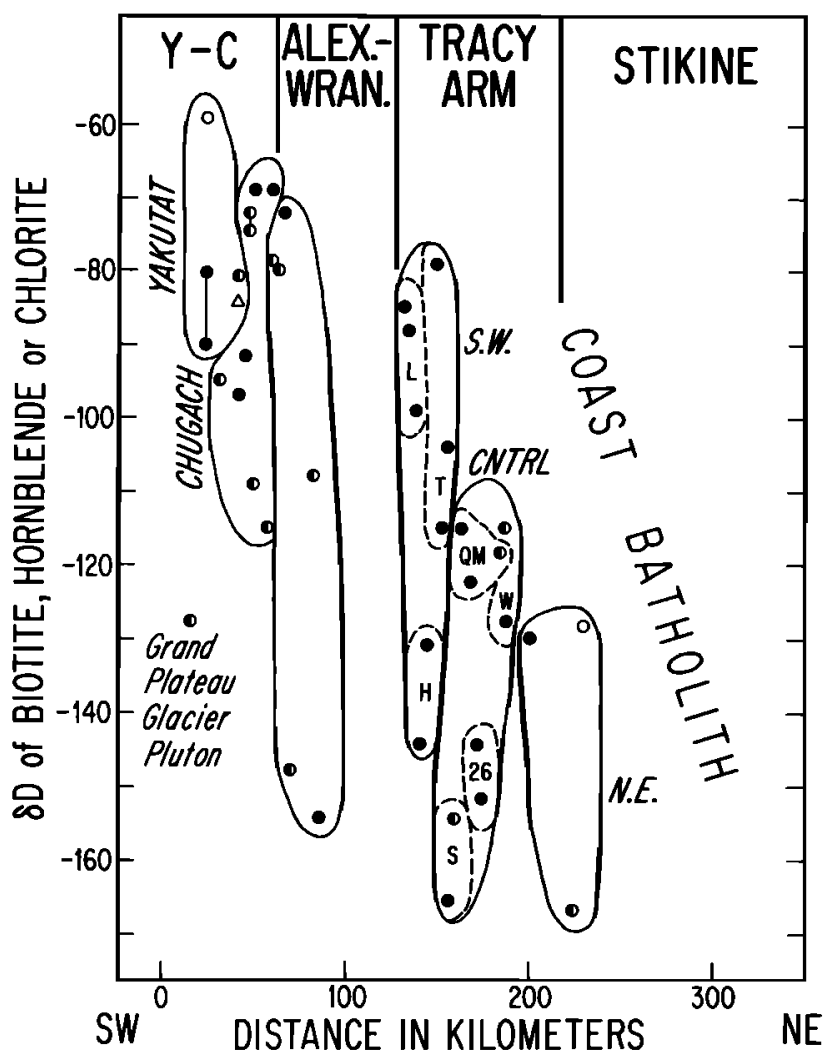

Fig. 16. A diagram of the same type shown in Figures 7 and 15, at the same scale, showing $\delta \mathrm{D}$ data from the Yakutat-Mount St. Elias and Skagway traverses (areas 1 and 2 on Figure 1) [after Magaritz and Taylor, 1976b]. The Coast Batholith plutons are subdivided into three groups, southwestern (S.W.), central (CNTRL), and northeastern (N.E.). The latter are all quartz monzonites (QM), as are some of the plutons of the Central Group; the other plutons are all tonalites; L, Lutak Inlet; T, Taiya River; H, Halatu Ridge; W, Whitehorse Pass; S, Skagway; 26, Mile 26. Y-C, Yakutat-Chugach Terranes. Alex.-Wran., Alexander-Wrangellia terranes. Distance is measured northeastward from the Pacific Coast. The different symbols are explained in Figure 7.

(particularly in the PRB). Why should this be? It seems appropriate to appeal to the complex superposition of Cenozoic and late Mesozoic intrusive events in the north, as well as to the much more complex reshuffling of the various plutonic and tectonostratigraphic terranes that make up the YakutatSkagway-Yukon region. The complex Mesozoic and Cenozoic tectonic activity has produced a myriad of small, more elongate, and sliverlike terranes in the north. This could have either "mixed up" any $\delta^{18} \mathrm{O}$ asymmetry originally present in the plutonic rocks, or else the premagmatic tectonic reshuflling could have caused a complex superposition of the various source materials that were ultimately melted to form the granitic magmas. Obviously, much more detailed isotopic and age studies will need to be carried out to sort out these complex relationships. In any case, there is certainly a striking contrast between the simple geological, isotopic, and age patterns in the PRB [Taylor and Silver, 1978; Silver et al., 1979] as compared to the analogous plutonic arcs in British Columbia. Perhaps the most remarkable thing is that the $\delta^{18} \mathrm{O}$ asymmetry is as simple as it appears to be in southern British Columbia, considering the structural and plutonic complexity of that region.

Figures 15 and 16 were constructed in order to make a direct comparison of $\delta \mathrm{D}$ values at the same scale as the cross section across southern British Columbia shown in Figure 7.
Generally similar features are shown by all three diagrams, clearly indicating a west-to-east decrease in the $\mathrm{D} / \mathrm{H}$ ratio of late Cretaceous to mid-Tertiary hydrothermal fluids throughout the entire length of British Columbia.

In the Prince Rupert-Prince George traverse, all of the samples across the entire width of the Stikine Terrane show evidence for meteoric-hydrothermal alteration by low- $\delta \mathrm{D}$ fluids. However, the more deeply seated plutons in the Western Coast Batholith do not shown any such $\mathrm{D} / \mathrm{H}$ effects nor do the sedimentary, volcanic, and metamorphic rocks of the Cache Creek and Quesnel Terranes farther east (Figure 15). The lizardite-chrysotile serpentines in the latter two terranes clearly indicate interaction with low- $\delta \mathrm{D}$ groundwaters, but this could have occurred much later and at much lower temperatures. The sedimentary and volcanic rocks to the west of the Cache Creek and Quesnel terranes were thoroughly "soaked" during the early Tertiary by hydrothermal fluids associated with the Eocene porphyry intrusions that are abundant throughout this part of the Stikine Terrane. However, note that the Jurassic Topley plutons preserve evidence of a higher- $\delta \mathrm{D}$ event that was not completely wiped out by the hydrothermal effects associated with the Tertiary intrusive event. The terrane boundaries in this region show up on Figure 15 as discontinuities in $\delta \mathrm{D}$, strongly suggesting that there has been at least some disruption and relative horizontal displacement along these boundaries subsequent to the main episode of Eocene hydrothermal activity. Also, even though the $\delta \mathrm{D}$ values are all typically quite low in the Stikine Terrane, the calculated waters are $20-30 \%$ higher than the present-day waters in this part of British Columbia (Figure 8). This is compatible with either a secular climatic change or some northward translation of these terranes (or both) subsequent to the Eocene hydrothermal activity.

Most of the statements made above apply equally as well to the Yakutat-Skagway traverse shown in Figure 16. The evidence for hydrothermal alteration is widespread and the same general west-to-east lowering of $\delta \mathrm{D}$ is observed. However, there is no real indication of any $\delta \mathrm{D}$ discontinuity across any of the terrane boundaries. This northwest traverse has a very complicated intrusive history, with plutonic activity ranging from late Paleozoic to late Tertiary, and much more detailed studies would be required to sort out any such discontinuties. It seems clear from these data and the work of Barker et al. [1984] that the most important meteoric-hydrothermal event recorded in these rocks occurred during the Eocene (48-54 Ma). This particularly applies to the Central plutons from the Coast Batholith near Skagway, particularly the Skagway tonalite pluton ( $S$ in Figure 16).

Summing up, for about $3000 \mathrm{~km}$ from the Skagway area to the Idaho Batholith and farther south [Taylor and Magaritz, 1978; Criss and Taylor, 1983], our work has demonstrated (1) the existence of a strong west-to-east asymmetry in the $\delta \mathrm{D}$ values of almost all plutonic igneous rocks along the entire length of the northwest North American cordillera, with $\delta \mathrm{D}$ decreasing eastward toward the continental interior, and (2) that this asymmetry was largely produced as a result of intense meteoric-hydrothermal alteration during a very widespread Eocene plutonic-volcanic event that occurred throughout this region about $40-50 \mathrm{Ma}$, superimposed upon a somewhat similar earlier event(s) that took place during the late Mesozoic.

Acknowledgments. This work was supported by the National Science Foundation grants DES 71-00510A03, EAR-7816874, and EAR 7621310. We are grateful to G. J. Woodsworth and J. A. Roddick supplying some of the samples analyzed in this study. We are also 
grateful for discussions and data provided by G. J. Woodsworth, L. S. Hollister, J. A. Roddick, J. Saleeby, and R. L. Armstrong and particularly to George E. Gehrels, who supplied a great deal of much needed information and insight into the geology of British Columbia and Alaska. Contribution 4141, Division of Geological and Planetary Sciences, California Institute of Technology, Pasadena, California.

\section{REFERENCES}

Archibald, D. A., J. K. Glover, R. A. Price, E. Farrar, and D. M. Carmichael, Geochronology and tectonic implications of magmatism and metamorphism, southern Kootenay Arc and neighboring regions, southeastern British Columbia, I, Jurassic to midCretaceous, Can. J. Earth Sci., 20, 1891-1913, 1983.

Archibald, D. A., T. E. Krogh, R. L. Armstrong, and E. Farrar, Geochronology and tectonic implications of magmatism and metamorphism, southern Kootenay Arc and neighboring regions, southeastern British Columbia, II, mid-Cretaceous to Eocene, Can. J. Earth Sci., 21, 567-583, 1984.

Armstrong, R. L., and D. Runkle, Rb-Sr geochronometry of the Ecstall, Kitkiata, and Quottoon plutons and their country rocks, Prince Rupert region, Coast Plutonic Complex, British Columbia, Can. J. Earth Sci., 16, 387-399, 1979.

Barker, F., J. G. Arth, and T. W. Stern, Traverse across the Coast Batholith, Skagway, Alaska and British Columbia (abstract), Geol. Soc. Am. Abstr. Programs, 16, 268, 1984.

Beck, M. E., Jr., R. F. Burmester, D. C. Engebretsen, and R. Schoonover, Northward translation of Mesozoic batholiths of western North America: Paleomagnetic evidence and tectonic significance, Geofis. Int., 20, 143-162, 1981.

Berry, M. J., W. R. Jacoby, E. R. Niblett, and R. A. Stacey, A review of geophysical studies in the Canadian Cordillera, Can. J. Earth Sci., 8, 788-801, 1971.

Campbell, R. B., and H. W. Tipper, Geology of Bonaparte Lake map-area, British Columbia, Mem. Geol. Surv. Can., 363, 100 pp., 1971.

Carlisle, D., and T. Susuki, Emergent basalt and submergent carbonate-clastic sequences including the Upper Triassic Dillen and Wellen zones on Vancouver Island, Can. J. Earth Sci., II, 254-279, 1974.

Carson, D. J. T., The plutonic rocks of Vancouver Island, Geol. Surv. Pap. Geol. Surv. Can., 72-44, 70 pp., 1973.

Chrismas, L., H. Baadsgaard, R. E. Folinsbee, P. Fritz, H. R. Krouse, and $\mathrm{A}$. Sasake, $\mathrm{Pb} / \mathrm{Sr}, \mathrm{S}$, and $\mathrm{O}$ isotope analyses indicating source and data of pyrometasomatic copper deposits at Craigmont, British Columbia, Econ. Geol., 63, 702-703, 1968.

Clark, I. D., P. Fritz, F. A. Michel, and J. G. Souther, Isotope hydrogeology and geothermometry of the Mt. Meager geothermal area, Can. J. Earth Sci., 19, 1454-1473, 1982.

Coney, P. J., D. L. Jones, and J. W. H. Monger, Cordilleran suspect terranes, Nature, 288, 329-333, 1980.

Craig, $H$., The isotope geochemistry of water and carbon in geothermal areas, in Nuclear Geology on Geothermal Areas, edited by $\mathrm{E}$. Tongiorgi, pp. 17-53, Consigilio Nacionale della Ricerche Laboratorio de Geologia Nucleare, Pisa, 1963.

Criss, R. E., and H. P. Taylor, An ${ }^{18} \mathrm{O} /{ }^{16} \mathrm{O}$ and $\mathrm{D} / \mathrm{H}$ study of Tertiary hydrothermal systems in the southern half of the Idaho batholith, Geol. Soc. Am. Bull., 94, 640-663, 1983.

Criss, R. E., M. A. Lanphere, and H. P. Taylor, Effects of regional uplift, deformation, and meteoric-hydrothermal metamorphism on K-Ar ages of biotites in the southern half of the Idaho batholith, $J$. Geophys. Res., 87, 7029-7046, 1982.

Eslinger, E. V., and S. M. Savin, Oxygen isotope geothermometry of the burial metamorphic rocks of the Precambrian Belt Supergroup, Glacier National Park, Montana, Geol. Soc. Am. Bull., 84, 2549$2560,1973$.

Fairbairn, H. W., P. H. Hurley, and W. K. Pinson, Initial ${ }^{87} \mathrm{Sr} /{ }^{86} \mathrm{Sr}$ and possible sources of granitic rocks, southeastern British Columbia, J. Geophys. Res., 69, 4889-4893, 1964.

Forester, R. W., and H. P. Taylor, ${ }^{18} \mathrm{O} /{ }^{16} \mathrm{O}, \mathrm{D} / \mathrm{H}$, and ${ }^{13} \mathrm{C} /{ }^{12} \mathrm{C}$ studies of Tertiary igneous complex of Sky, Scotland, Am. J. Sci., 277, 136-177, 1977.

Friedman, I., A. C. Redfield, B. Schoen, and J. Harris, The variation of the deuterium content of natural waters in the hydrologic cycle, Rev. Geophys., 2, 177-224, 1964.

Gabrielse, H., and J. E. Reesor, The nature and setting of granitic plutons in the central and eastern parts of the Canadian Cordillera, Pac. Geol., 8, 109-138, 1974.

Gehrels, G. E., and H. P. Taylor, Jr., Fossil hydrothermal systems in the Ketchikan Area, Southeastern Alaska, U.S. Geol. Surv. Circ., $868,134-137,1984$.
Godfrey, J. D., The deuterium content of hydrous minerals from eastcentral Sierra Nevada and Yosemite National Park, Geochim. Cosmochim. Acta, 26, 1215-1245, 1962.

Godwin, C. I., Imbricate subduction zones and their relationship with Upper Cretaceous to Tertiary Porphyry deposits in the Canadian Cordillera, Can. J. Earth Sci., 12, 1362-1378, 1975.

Hillhouse, J. W., and C. S. Gromme, Northward displacement and accretion of Wrangellia: New paleomagnetic evidence from Alaska, J. Geophys. Res., 89, 4461-4477, 1984.

Hitchon, B., and H. R. Krouse, Hydrogeochemistry of the surface waters of the MacKensie River drainage basin, Canada, III, Stable isotopes of oxygen, carbon, and sulphur, Geochim. Cosmochim. Acta, 36, 1337-1357, 1972.

Hollister, L. S., Metamorphic evidence for rapid ( $2 \mathrm{~mm} / \mathrm{yr})$ uplift of a portion of the Central Gneiss Complex, Coast Mountains, British Columbia, Can. Mineral., 20, 319-332, 1982.

Hudson, T., G. Plafker, and M. A. Lanphere, Intrusive rocks of the Yakutat-St. Elias area, south-central Alaska, J. Res. U.S. Geol. Surv., 5, 155-172, 1977.

Hutchison, W. W., Geology of the Prince Rupert-Skeena map area, British Columbia, Mem. Geol. Surv. Can., 394, 116 pp., 1982.

Jones, D. L., N. J. Silberling, and J. Hillhouse, Wrangellia-A displaced terrane in northwestern North America, Can. J. Earth Sci., 14, 2565-2577, 1977.

Kuniyoshi, S., and J. G. Liou, Contact metamorphism of the Karmutsen Volcanics, Vancouver Island, British Columbia, J. Petrol., 17, 73-99, 1976.

Leech, G. B., J. A. Lowden, R. K. Stockwell, and R. K. Wanless, Age determinations and geological studies, Geol. Surv. Pap. Geol. Surv. Can., 63-17, 140 pp., 1963.

Little, H. W., Nelson map-area, west half, British Columbia $(82 \mathrm{FW}$ 1/2), Geol. Surv. Can. Mem. 308, 205 pp., 1960.

Lowdon, J. A., Age determinations by the Geological Survey of Canada, Geol. Surv. Can. Pap. 61-17, 127 pp., 1961.

Magaritz, M., and H. P. Taylor, $\mathrm{J}_{r} .{ }^{19} \mathrm{O} /{ }^{16} \mathrm{O}$ and $\mathrm{D} / \mathrm{H}$ studies along a $500 \mathrm{~km}$ traverse across the Coast Range batholith and its country rocks, central British Columbia, Can. J. Earth Sci., 13, 1514-1536, $1976 a$.

Magaritz, M., and H. P. Taylor, Jr., Isotopic evidence for meteorichydrothermal alteration of plutonic igneous rocks in the Yakutat Bay and Skagway areas, Alaska, Earth Planet. Sci. Lett., 30, 179$190,1976 b$.

Magaritz, M., and H. P. Taylor, Jr., Oxygen, hydrogen and carbon isotope studies of the Franciscan Formation, Coast Ranges, California, Geochim. Cosmochim. Acta, 40, 215-234, 1976c.

Masi, U., J. R. O'Neil, and R. W. Kistler, Stable isotope systematics in Mesozoic granities of central and northern California and southwest Oregon, Contrib. Mineral. Petrol., 76, 116-126, 1981.

Mathews, W. H., Early Tertiary resetting of potassium-argon dates and geothermal history of north Okanagan area, British Columbia, Can. J. Earth Sci., 20, 1310-1319, 1981.

Mathews, W. H., Early Tertiary resetting of potassium-argon dates in the Kootenay area, southeastern British Columbia, Can. J. Earth Sci., 20, 867-872, 1983.

Medford, G. A., K-Ar and fission track geochronology of an Eocene thermal event in the Kettle River (west half) map area, southern British Columbia, Can. J. Earth Sci., 12, 836-843, 1975.

Medford, G. A., R. L. Armstrong, and M. J. Osatenko, Rb-Sr dating of Paleozoic(?), Mesozoic, and Cenozoic intrusive rocks, Okanagan Lake region, southern British Columbia, Canada, Can. J. Earth Sci., 20, 1579-1585, 1983.

Monger, J. W. H., and H. C. Berg, Lithotectonic terrane map of western Canada and southeastern Alaska, Lithotectonic Terrane Map of the North American Cordillera, edited by N. J. Silberling and D. L. Jones, U.S. Geol. Surv. Open File Rep., 84-523, B1-B31, 1984.

Monger, J. W. H., and E. Irving, Northward displacement of northcentral British Columbia, Nature, 285, 289-294, 1980.

Monger, J. W. H., and R. A. Price, Geodynamic evolution of the Canadian Cordillera-Progress and problems, Can. J. Earth Sci., 16, 771-791, 1979.

Monger, J. W. H., R. A. Price, and D. J. Templeman-Kluit, Tectonic accretion and the origin of the two major metamorphic and plutonic belts in the Canadian Cordillera, Geology, 10, 70-75, 1982 .

Muller, J. E., Evolution of the Pacific Margin, Vancouver Island, and adjacent regions, Can. J. Earth Sci., 14, 2062-2085, 1977.

Nguyen, K. K., A. J. Sinclair, and W. G. Libby, Age of the northern part of the Nelson batholith, Can. J. Earth Sci., 5, 955-957, 1968.

Northcote, K. E., Geology and geochronology of the Guichon Creek Batholith, Bull. B. C. Dep. Mines Pet. Resour., 56, 1-73, 1969. 
O'Neil, J. R., and H. P. Taylor, Jr., The oxygen isotope and cation exchange chemistry of feldspars, Am. Mineral., 52, 1414-1437, 1967.

Panuska, B. C., and D. B. Stone, Late Paleozoic paleomagnetic data for Wrangellia: Resolution of the polarity ambiguity, Nature, 293, 561-563, 1981.

Parrish, R. R., Cenozoic thermal evolution and tectonics of the Coast Mountains of British Columbia, 1, Fission track dating, apparent uplift rates, and patterns of uplift, Tectonics, 2, 601-631, 1983.

Peto, P., Petrochemical study of the Similkameen batholith, British Columbia, Geol. Sco. Am. Bull., 84, 3977-3984, 1973.

Peto, P., Plutonic evolution of the Canadian Cordillera, Geol. Soc. Amer. Bull., 85, 1269-1276, 1974.

Peto, P., Plutonic evolution of the Canadian Cordillera: Reply, Geol. Soc. Amer. Bull., 86, 1612-1613, 1975.

Peto, P., and R. L. Armstrong, Strontium isotope study of the composite batholith between Princeton and Okanagan Lake, Can. J. Earth Sci., 13, 1577-1583, 1976.

Rice, H. M. A., Nelson map area, east half, British Columbia, Geol. Survey Canada, Mem. 228, 86 pp, 1941.

Roddick, J. A., Geophysical review and composition of the Coast Plutonic Complex, south of latitude $55^{\circ} \mathrm{N}$, Geol. Soc. Amer., Mem. 159, 195-211, 1983.

Roddick, J. A., and W. W. Hutchison, Setting of the Coast Plutonic Complex, British Columbia, Pac. Geol., 8, 91-108, 1974.

Saleeby, J. B., Accretionary tectonics of the North American Cordillera, Annu. Rev. Earth Planet. Sci., 15, 45-73, 1983.

Sheppard, S. M. F., R. L. Nielsen, and H. P. Taylor, Jr., Hydrogen and oxygen isotope ratios in minerals from porphyry copper deposits, Econ. Geol., 66, 515-542, 1971.

Silver, L. T., H. P. Taylor, Jr., and B. Chappell, Some petrological, geochemical, and geochronological observations of the Peninsular Ranges batholith near the international border of the U.S.A. and Mexico, in Mesozoic Crystalline Rocks: Peninsular Ranges Batholith and Pegmatites, Pt. Sal Ophiohte, Guidebook Geological Society of America Meeting, San Diego, edited by P. C. Abbott and V. R. Todd, pp. 83-110, San Diego State University, San Diego, Calif., 1979.

Solomon G. C., and H. P. Taylor, Jr., The geographic distribution of $\delta^{18} \mathrm{O}$ values in Mesozoic and early Cenozoic granitic rocks of the southwestern North American cordillera (abstract), Geol. Soc. Am. Abstr. Programs, 13, 558, 1981.

Stone, D. E., B. C. Panuska, and D. R. Packer, Paleolatitudes versus tıme for southern Alaska, J. Geophys. Res., 87, 3677-3707, 1982.

Suzuoki, T., and S. Epstein, Hydrogen isotope fractionation between $\mathrm{OH}$-bearing silicate minerals and water, Geochim. Cosmochim. Acta, $40,1229-1240,1976$.

Symons, D. T. A., New paleomagnetic data for the Truassic Guichon batholith of south-central British Columbia and their bearing on Terrane I tectonics, Can. J. Earth Scl., 20, 1340-1344, 1983a.

Symons, D. T. A., Further paleomagnetic results from the Jurassic Topley intrusives in the Stıkinıa subterrane of British Columbia, Geophys. Res. Lett., 10, 1065-1068, $1983 b$.

Symons, D. T. A., and C. R. Litalien, Paleomagnetısm of the Lower Jurassic Copper Mountain intrusions and the geotectonics of Terrane I, British Columbia, Geophys. Res. Lett., 11, 685-688, 1984.

Taylor, H. P., Jr., The oxygen isotope geochemistry of igneous rocks, Contrib., Mineral Petrol., 19, 1-71, 1968

Taylor, H. P., Jr., Oxygen and hydrogen isotope evidence for largescale circulation and interaction between ground waters and igneous intrusions, with particular reference to the San Juan volcanic field, Colorado, Geochemical Transport and Kinetics, edited by A. W. Hofmann, B. J. Giletti, H. S. Yoder, and R. A. Yund, Carnegle Inst. Washington Publ., 634, 299-324, 1974a.

Taylor, H. P., Jr., The application of oxygen and hydrogen isotope studies to problems of hydrothermal alteration and ore deposition, Econ. Geol., 69, 843-884, $1974 b$.
Taylor, H. P., Jr., Water/rock interactions and the origin of $\mathrm{H}_{2} \mathrm{O}$ in granitic batholiths, J. Geol. Soc. London, 133, 509-558, 1977.

Taylor, H. P., Jr., Oxygen and hydrogen isotope studies of hydrothermal interactions at submarine and subaerial spreading centers, in Hydrothermal Processes at Seafloor Spreading Centers, NATO Conf. Ser. Mar. Sci., vol. 12, edited by P. A. Rona, K. Bostrom, L. Laubier, and K. L. Smith, pp. 83-139, Plenum, New York, 1983.

Taylor, H. P., Jr., and S. Epstein, Relationship between ${ }^{18} \mathrm{O} /{ }^{16} \mathrm{O}$ ratios in coexisting minerals of igneous and metamorphic rocks, part I, Geol. Soc. Am. Bull., 73, 461-480, 1962a.

Taylor, H. P., Jr., and S. Epstein, Relationship between ${ }^{18} \mathrm{O} /{ }^{16} \mathrm{O}$ ratios in coexisting minerals of igneous and metamorphic rocks, part II, Geol. Soc. Am. Bull., 73, 675-694, $1962 b$.

Taylor, H. P., Jr., and R. W. Forester, Low- ${ }^{18} \mathrm{O}$ igneous rocks from the intrusive complexes of Skye, Mull and Ardnamurchan, western Scotland, J. Petrol., 12, 465-497, 1971.

Taylor, H. P., and R. W. Forester, An oxygen and hydrogen isotope study of the Skaergaard intrusion and its country rocks: A description of a 55-m.y.-old fossil hydrothermal system, J. Petrol., 20, 355-419, 1979.

Taylor, H. P., Jr., and M. Magaritz, Oxygen and hydrogen isotope studies of the Cordilleran batholiths of western North America, Stable Isotopes in the Earth Sciences (Rafter Volume), edited by B. W. Robinson, Bull. N. Z. Dep. Sci. Ind. Res., 220, 151-173, 1978.

Taylor, H. P., Jr., and L. T. Silver, Oxygen isotope relationships in plutonic igneous rocks of the Peninsular Ranges batholith, southern and Baja California, U.S. Geol. Surv. Open File Rep., 78-701, 423-427, 1978.

Wanless, R. K., R. D. Stevens, G. R. Lachance, and R. N. D. Delabio, Age determinations and geological studies, Geol. Surv. Pap. Geol. Surv. Can., 74-2, 72 pp., 1974.

Wanless, R. K., R. D. Stevens, G. R. Lachance, and R. N. D. Delabio, Age determinations and geological studies, Geol. Surv. Pap. Geol. Surv. Can., 79-2, 67 pp., 1979.

Wenner, D. B., and H. P. Taylor, Jr., Oxygen and hydrogen isotope studies of a Precambrian granite-rhyolite terrane, St. Francois Mtns., southeastern Missouri, Geol. Soc. Am. Bull., 87, 1587-1598, 1976.

Woodsworth, G. J., Metamorphism, deformation, and plutonism in the Mount Raleigh pendant, Coast Mountains, British Columbia, Bull. Geol. Surv. Can., 295, 1-51, 1980.

Woodsworth, G. J., W. D. Loveridge, R. R. Parrish, and R. W. Sullivan, Uranium-lead dates from the central gneiss complex and Ecstall pluton, Prince Rupert map area, British Columbia, Can. J. Earth Sci., 20, 1475-1483, 1983.

Yapp, C. J., and S. Epstein, A reexamination of cellulose carbonbound hydrogen $\delta \mathrm{D}$ measurements and some factors affecting plant-water D/H relationships, Geochim. Cosmochim. Acta, 46, 955965, 1982.

Yole, R. W., and E. Irving, Displacement of Vancouver Island: Paleomagnetic evidence from the Karmutsen Formation, Can. J. Earth Sci., $17,1210-1228,1980$.

M. Magaritz, Department of Isotope Research, Weizmann Institute of Science, Rehovet 76100 , Israel.

H. P. Taylor, Jr., Division of Geological and Planetary Sciences, California Institute of Technology, MS/170-25, 1201 E. Californa Blvd., Pasadena, CA 91125.
(Received January 22, 1985 ; revised October 11, 1985; accepted October 14, 1985.) 